NBER WORKING PAPER SERIES

\title{
LIFE-CYCLE SAVING, LIMITS ON CONTRIBUTIONS TO DC PENSION PLANS, AND LIFETIME TAX BENEFITS
}

\author{
Jagadeesh Gokhale \\ Laurence J. Kotlikoff \\ Mark J. Warshawsky
}

Working Paper 8170

http://www.nber.org/papers/w8170

\author{
NATIONAL BUREAU OF ECONOMIC RESEARCH \\ 1050 Massachusetts Avenue \\ Cambridge, MA 02138 \\ March 2001
}

We thank Mary DiCarlantonio and Shana Neiditch for excellent research assistance and William Gale, Leslie Papke, Annika Sunden, Peter Weinberg, David Wise, and other participants at the "Public Policies and Private Pensions" conference held at the Brookings Institution on September 21-22, 2000 for helpful comments. Professor Kotlikoff thanks Boston University and the National Institute of Aging for research support. The views expressed herein are those of the authors and not necessarily those of the National Bureau of Economic Research, Boston University, TIAA-CREF, or the Federal Reserve Bank of Cleveland.

(C) 2001 by Jagadeesh Gokhale, Laurence J. Kotlikoff and Mark J. Warshawsky. All rights reserved. Short sections of text, not to exceed two paragraphs, may be quoted without explicit permission provided that full credit, including $\odot$ notice, is given to the source. 
Life-Cycle Saving, Limits on Contributions to DC Pension Plans, and Lifetime Tax Benefits Jagadeesh Gokhale, Laurence J. Kotlikoff and Mark J. Warshawsky

NBER Working Paper No. 8170

March 2001

JEL No. D9

\begin{abstract}
This paper addresses three questions related to limits on DC contributions. The first is whether statutory limits on tax-deductible contributions to defined contribution (DC) plans are likely to be binding, focusing on households in various economic situations. The second is how large is the tax benefit from participating in defined contribution plans. The third is how does the defined contribution tax benefit depend on the level of lifetime income. We find that the statutory limits bind those older middle-income households who started their pension savings programs late in life, those who plan to retire early, single-earner households, those who are not borrowing constrained, and those with rapid rates of real wage growth. Most households with high levels of earnings, regardless of age or situation, are also constrained by the contribution limits.

Lower or middle-income two-eamer households that can look forward to modest real earnings growth are likely to be borrowing constrained for most of their pre-retirement years because of the costs of paying a mortgage and sending children to college. These households are not in a position to save the 25 percent of earnings allowed as a contribution to DC plans. Some of these middle-income households, however, are constrained by the $\$ 10,500$ limit on elective employee contributions to $401(\mathrm{k})$ plans if the households have access to only these plans and their employers make no pension contributions for them. The borrowing constraints faced by many lower- and middle-income Americans means that contributions to DC plans must come at the price of lower consumption when young and the benefit of higher consumption when old. Indeed, for a stylized household earning $\$ 50,000$, consistently contributing 10 percent of salary to a DC plans that earns a 4 percent real return means consuming almost two times more when old than when young.

Measured as a share of lifetime consumption, the tax benefit from participating in a DC plan can be significant. Assuming annual contribution rates at the average of the maximum levels allowed by employers in 401 (k) plans and assuming a 4 percent real return on DC and non-DC assets, the benefit is 2 percent for two-earner households earning $\$ 25,000$ per year, 3.4 percent for those earning $\$ 100,000$ per year, and 9.8 percent for those earning $\$ 300,000$ per year. Contribution ceilings limit the benefit at the highest regions of the household earnings distribution. The extent of the benefit is also quite sensitive to the assumed rate of return on DC and non-DC assets.
\end{abstract}

Jagadeesh Gokhale

The Federal Reserve Bank of Cleveland

Mark J. Warshawsky

The TIAA-CREF Institute
Laurence J. Kotlikoff

Boston University

and NBER 


\section{Introduction}

It is now over a quarter of century since the passage of the Employee Retirement Income Security Act (ERISA). This law regulates tax-favored vehicles for retirement saving, including defined contribution (DC) pension accounts. A key element of ERISA's DC provisions is the setting of limits on the size of tax-deductible contributions. In both nominal and, especially, inflation-adjusted terms, these limits have been tightened over the years. Current rules allow workers and their employers jointly to contribute, on an annual basis, the lesser of 25 percent of a worker's earnings or $\$ 30,000$ to a DC plan. There is also a separate limit of $\$ 10,500$ on that

part of the joint contribution (the elective contribution) made by employees. In the case of 401(k)-type plans in which the employer makes no contribution, $\$ 10,500$ is the relevant limit on contributions. If the employer doesn't sponsor a plan, a worker is limited to $\$ 2,000$ in contributions to an IRA.

Congress is now considering legislation to increase the various limits on tax-deductible contributions to retirement accounts. The policymakers' interest in this issue is understandable. More and more workers are saving for retirement primarily through DC and IRA plans. And limiting contributions to retirement accounts raises concerns about the adequacy of retirement saving. These concerns arise, in part, from studies by Warshawsky and Ameriks (2000), Bernheim, Forni, Gokhale, and Kotlikoff (2000), and others suggesting that many Americans are saving too little to sustain their current living standards in old age and the well-known fact that many workers are not covered by either defined benefit or defined contribution pension plans.

Would raising the joint employer-employee contribution limit in DC plans matter? Or is the real issue raising the elective employee or IRA limits, or the limits for older workers, or, indeed, simply getting employers and participants who are now contributing below the limits to increase their contributions or to set up retirement plans? The government does provide a significant tax benefit for most households to encourage full participation. Contributions to retirement plans are tax-deductible. Although withdrawals are taxable, there is no federal or state taxation of the capital income accrued prior to withdrawal. ${ }^{1}$ Compared to saving outside of retirement accounts, this deferral of tax payments gives workers an interest-free loan on the taxes they would 
otherwise have paid on a) the original contribution plus b) all subsequent capital income earned on the

- contribution. The result is that the capital income component of income taxation is effectively eliminated for income earned and invested in retirement accounts.

Because the poor and the low-income face low rates of income taxation and have a significantly larger share of their pre-retirement earnings replaced by Social Security, the DC joint employer-employee contribution limits seem to have been set with the middle, upper-middle, and high-income classes in mind. The goal of the joint limit appears to be to permit middle- and upper-middle class households to save significant sums on a taxfavored basis to fund a comfortable retirement, while limiting the tax-break available to the rich. This approach also limits the short-term losses in aggregate tax revenues for the federal government. ${ }^{2}$

This paper addresses three questions related to limits on DC contributions. The first is whether statutory limits on tax-deductible contributions to defined contribution (DC) plans are likely to be binding, focusing on households in various economic situations. The second is how large is the tax benefit from participating in defined contribution plans. The third is how does the defined contribution tax benefit depend on the level of lifetime income. To be precise, we determine whether stylized households that differ by their ages, levels of lifetime earnings, past pension coverage, planned retirement dates, and so on would want to contribute more than the maximum allowable amounts. We also measure, as a percent of lifetime consumption, the lifetime tax benefit provided to households from participating in DC plans and show how this benefit varies by level of lifetime earnings. Stated differently, we calculate the percentage increase in the present value of lifetime consumption of households resulting from participation in DC plans.

The methodology used in this paper is simulations, that is, to run a number of stylized households through Economic Security Planner (ESPlanner), a sophisticated planning model of optimal saving and

\footnotetext{
1 This discussion abstracts from Roth IRAs.

2 DC contribution limits also constrain the amount of tax arbitrage possible under the system. Tax arbitrage, in this context, refers to borrowing on a tax-deductible basis and using the proceeds to make contributions. Borrowing on a tax-deductible basis means that interest paid on such borrowing is tax-deductible. Because, as just indicated, interest earned on funds invested in DC plans is effectively untaxed, tax arbitrage here amounts to borrowing on an after-tax basis and lending on a pre-tax basis. Current tax law
permits deducting interest payments only on mortgages and home equity loans, and therefore such tax arbitrage is constrained by the degree to which DC contributors can leverage their homes.
} 
consumption over the life cycle. We use the model to evaluate the questions posed above, and, more broadly, to

- discuss the current policy stance toward retirement saving.

We find that the statutory limits bind those older middle-income households who started their pension savings programs late in life, those who plan to retire early, single-earner households, those who are not borrowing constrained, and those with rapid rates of real wage growth. Most households with high levels of earnings, regardless of age or situation, are also constrained by the contribution limits. Lower or middleincome two-earner households that can look forward to modest real earnings growth are likely to be borrowing constrained for most of their pre-retirement years because of the costs related paying a mortgage and to having children who will go to college. These households are not in a position to save the 25 percent of earnings allowed as a contribution to DC plans. Some of these middle-income households, however, are constrained by $\$ 10,500$ limit on elective employee contributions to $401(\mathrm{k})$ plans if the households have access to only these plans and their employers make no pension contributions on their behalf.

The borrowing constraints faced by many lower- and middle-income Americans means that contributions to DC plans come at the price of lower consumption when young and the benefit of higher consumption when old. Indeed, for a stylized household we consider, contributing 10 percent of salary to a DC plans that earns a 4 percent real return means consuming almost two times more when old than when young.

The tax benefit from participating in a DC plan can be significant. Assuming annual contribution rates at the average of the maximum levels allowed by employers and assuming a 4 percent real return on DC and non-DC assets, the benefit is 2 percent for two-earner households earning $\$ 25,000$ per year, 3.4 percent for those earning $\$ 100,000$ per year, and 9.8 percent for those earning $\$ 300,000$ per year. Contribution limits effectively limit the benefit only at the highest regions of the household earnings distribution. The extent of the benefit is also quite sensitive to the assumed rate of return on DC and non-DC assets.

The significant value of the DC tax benefit combined with the distortions it conveys to age-consumption profiles suggest the need to re-examine the structure of the tax preference provided to defined contribution plans. In theory, contribution limits to DC plans should be designed on a lifetime basis and reflect the 
household's history of contributions made and the extent of provisions already made for funding retirement. In

- practice, the administrative requirements and costs for this individualized approach are terribly high, and hence simple and "one-size-fits-all" rules must be designed. Therefore, the practical implications of our findings is that consideration should be given to higher contribution limits for older workers than younger workers, unconstrained by non-discrimination requirements. Similarly, consideration to an increase in the $401(\mathrm{k})$ and 403(b) contribution limits also seems appropriate, as many upper-middle-income households are potentially constrained by them. Furthermore, modification of the non-discrimination requirements to easily allow ageweighted DC plans may be warranted given the general indication that savings should be more concentrated in the ages just before retirement. Fairness would seem to dictate that the benefits of participation in taxadvantaged savings plans be widely shared by all workers regardless of whether their employer sponsors a pension plan or not, and regardless of how much the employer contributes, if anything. In the current setting, achieving more uniform treatment of employees could be accomplished by raising tax-deductible IRA contribution limits.

The paper proceeds in Section II with a brief review of DC contribution limits. Section III describes ESPlanner. Section IV considers the degree to which the DC limits are binding. Section V shows how participating in DC plans alters consumption growth over the life cycle for our stylized households. Section VI presents DC subsidy rates under alternative assumptions. And Section VII summarizes and concludes the study.

\section{Limits on DC Contributions}

Section 415 was added to the Internal Revenue Code by ERISA in 1974 and it limited contributions to DC plans to the lesser of $\$ 25,000$ or 25 percent of compensation. The dollar limitations were adjusted for inflation and by 1982 had risen to $\$ 45,472$. Effective in 1983 , federal law was amended and reduced the contribution limit to $\$ 30,000$. Although this new limit was supposed to have been adjusted for inflation, law passed in 1984 froze the adjustments through 1988. 
The Tax Reform Act of 1986 governs current policy. Contributions for and by an employee to all DC

" plans maintained by an employer may not exceed the lesser of $\$ 30,000$ (or, if greater, one-quarter of the benefit dollar limitation allowed for defined benefit (DB) plans), and 25 percent of the participant's compensation. The Tax Reform Act of 1986 set the dollar limitation for DB plan benefits at $\$ 120,000$ and no inflation adjustments occurred until 1997. The law provides that any inflation adjustment that is not a multiple of $\$ 5,000$ should be rounded to the next lowest multiple of $\$ 5,000$. Hence, even though the DB limit in 2000 had reached $\$ 135,000$, the dollar limit for DC plans in 2000 still remains at $\$ 30,000$. The DC limit will increase to $\$ 35,000$ in 2001 as the DB limit increases to $\$ 140,000$.

Chart 1 shows contribution limits to DC plans since 1982 in nominal and inflation-adjusted terms. Since 1983 , inflation has eroded the contribution limit, in July 1983 dollars, from $\$ 30,000$ to about $\$ 17,500$ in 2000 . Stated another way, if the $\$ 30,000$ limit of 1983 had been allowed to keep pace with inflation, it would be almost $\$ 52,000$ in 2000 ; if the $\$ 45,472$ limit in existence in 1982 had been allowed to keep pace with inflation, it would be almost $\$ 79,000$ in 2000 . Effectively, contribution limits to DC plans have been progressively tightened for the last two decades.

In addition to the overall joint employer-employee limit on contributions of the lesser of $\$ 30,000$ or 25 percent of salary, there are separate limits on employee contributions. Employee pretax ("elective") contributions are limited to $\$ 10,500$ in 2000 for $401(\mathrm{k})$ and $403(\mathrm{~b})$ plans and are coordinated with elective contributions to SEPs, sec. 457 state and local government plans, tax-deferred 403(b) annuities, and.sec. 501 (c)(18) trusts. $^{3}$ The elective contribution limit is adjusted for inflation in $\$ 500$ increments. Employer contributions, whether basic or matching contributions, are limited to the overall limit less the employee contribution limit.

Contributions may also be further restricted by nondiscrimination rules (sections $401(\mathrm{a}) 4,401(\mathrm{k})$ and 401(m)), whereby a DC pension plan, in the actual experience of the plan, generally cannot have higher paid

\footnotetext{
${ }^{3}$ A special catch-up election under 403(b) plans applies to employees of educational organizations, home health service agencies, health and welfare service agencies, and church organizations. It applies only to employees with 15 or more years of service and may
} 
workers receiving higher contribution rates than lower paid workers. Furthermore, an employer is limited with

- respect to making tax-deductible contributions to a DC plan to 15 percent of the aggregate compensation of the employees covered by the plan. 403(b) plans are subject to an additional contribution limit, known as the "maximum exclusion allowance" or "MEA". It applies to both employer and employee contributions and generally limits contributions to 20 percent of an employee's compensation multiplied by the number of years of service with the employer less prior amounts contributed to a retirement plan.

The maximum total annual new contribution permitted to IRAs (including traditional deductible IRAs, Roth IRAs, and nondeductible IRAs) is the lesser of $\$ 2,000$ or $100 \%$ of the individual's compensation. Starting in 1997 , the limit for married couples was gradually increased to $\$ 4,000(\$ 2,000$ per spouse). The maximum IRA contribution limit has been set at $\$ 2,000$ since 1981 . An individual may make deductible contributions to an IRA if neither the individual nor the individual's spouse is an active participant in an employer-sponsored pension plan. If the individual or the spouse is an active participant in a pension plan, the $\$ 2,000$ deduction limit is phased-out for single taxpayers with adjusted gross incomes above $\$ 42,000$ and for married taxpayers with adjusted gross incomes above $\$ 62,000$.

As part of the "Taxpayer Relief Act of 2000," which was passed by the House of Representatives in October 2000, a substantial overhaul of the tax rules governing retirement plans was contemplated. These pension provisions were the result of several years of discussions and the introduction of various bills containing pension reform provisions. The Act was approved overwhelmingly by the House of Representatives, but dropped by the Senate in response to a threatened Presidential veto.

The Act would have raised the dollar limit for DC plans to $\$ 40,000$, subject to indexing in future years in $\$ 1000$ increments. The limitation on elective contributions to $401(\mathrm{k}), 403(\mathrm{~b})$, and 457 plans would have been raised to $\$ 15,000$ over five years, subject to indexing thereafter in $\$ 500$ increments. And the annual contribution limit for IRAs would have been raised over three years to $\$ 5,000$ and thereafter subject to indexing over the employee's lifetime. We did not consider this special catch-up elective deferral for purposes of this paper. 
$=$ in $\$ 500$ increments. The Act would also have increased from 25 to 100 percent the percentage of earnings limit

- on DC contributions and repealed the 403(b) MEA calculation.

Finally, the Act would have permitted workers age 50 and older to make additional annual "catch-up" contributions to DC plans of up to $\$ 5,000$ (phased in over five years), subject to indexing in $\$ 500$ increments. These additional contributions would not be subject to any other contribution limit, but would be subject to nondiscrimination tests.

In considering the DC limits, it's important to bear in mind that the effective limits workers face are determined by employer decisions, as well as by statute. Employers who offer no DC plan are, in effect, setting their workers' DC contribution limits to zero, and leaving their workers only the option of saving through IRAs, with their very low contribution limits. At any point in time, about half of the workforce has access to neither DC or DB (defined benefit) plans. As Poterba, Venti, and Wise (1999) document, recent growth in DC plans has raised to about 40 percent the share of the U.S. workforce covered by such plans. Nearly three-quarters of workers with 401(k)-type plans reported that they considered that plan as their primary retirement plan. At least a fifth of all participants in 401(k)-type plans in 1993 were enrolled in plans with no employer contributions, and about 35 percent of workers at firms sponsoring these plans either could not or did not participate.

Those employers who offer a DC plan with an employer match on employee contributions up to, say, 5 percent of pay are, perhaps unwittingly, suggesting that their workers contribute no more than 5 percent of their salary. In 1997, the modal employer match was 50 percent on employee contributions up to 6 percent of pay. ${ }^{4}$ The average employee elective contribution to these plans was 7.1 percent of compensation. ${ }^{5}$

The maximum pretax employee contribution allowed by employers in saving and thrift plans in 1997 averaged 13.7 percent; the maximum contribution rate allowed by employers ranged from 5 percent or less to 20 percent, with the mode at 15 percent. ${ }^{6}$ Apparently many plan sponsors are influenced by their workers'

\footnotetext{
4 See BLS (1999), table 152.

${ }^{5}$ See EBRI (1997), Chapter 12.

${ }^{6}$ See BLS (1999), table 150.
} 
preferences as well as by the operation of non-discrimination requirements and other legal factors in setting

- maximum allowable contribution rates.

Why don't workers in DC plans contribute to the maximum extent possible? The reasons given by 401(k) participants in the 1996 Retirement Confidence Survey are: cannot afford to save, too young to start saving for retirement, saving for a house, saving for children's college education, and difficult to withdraw funds. ${ }^{7}$ This survey also generated the following distribution of principal factors cited for determining 401(k) contributions: the maximum amount employer would match (21 percent), the most one could afford to contribute ( 31 percent), the maximum amount one is allowed to contribute ( 30 percent), the amount participants determined they should contribute ( 16 percent), and other ( 2 percent).

\section{ESPlanner}

The decision of when and how much to contribute to a DC plan involves a complex set of economic factors. First, workers have to consider their current federal plus state income-tax brackets to assess their immediate tax saving from making DC contributions. Second, workers have to project their future federal plus state income-tax brackets to assess the rate at which their future DC withdrawals will be taxed. For some households, contributing to DC plans smoothes the time-path of taxable income and lowers the levels of marginal tax rates they face, on average, as they age.

A third factor is the worker's scope to contribute without reducing current consumption. If workers could borrow as much as they'd like they'd be in a position to perfectly smooth their consumption regardless of how much they contributed to a DC plan. In contrast, workers that are borrowing constrained will have to lower their consumption when young in order to finance their DC contributions. ${ }^{8}$ Whether a worker faces

\footnotetext{
${ }^{7}$ EBRI (1997), Chapter 13.

${ }^{8}$ This will alter their entire time path of non-tax-favored asset accumulation, which, in turn, will mean a different time path of income taxes than would otherwise have been the case. It also leaves workers ending up in retirement with a higher living standard than they enjoy when young. For such workers, participation in DC plans, rather than smoothing marginal tax rates, may do the opposite because it leaves them with so much more taxable income in old age than would otherwise have been the case.
} 
borrowing constraints depends on his or her household's projected growth in future income and its "off-the-top" expenditures on housing and college and other special expenditures.

A fourth factor influencing the rate of DC subsidization is Social Security, specifically its progressive provision of benefits and regressive taxation of payroll. As documented in Gokhale, et. al. (1998), the Social Security system represents a lifetime net benefit to the very poor, but a lifetime net tax to low income, middle income, and high income households, with the rate of lifetime net taxation highest for those with middle incomes. In addition to affecting the level of consumable lifetime resources differentially for different households, Social Security differentially affects the degree to which different households are liquidity constrained. This arises, in part, because Social Security's benefit replacement rate is higher for low contributors and, in part, because the program's payroll tax ceiling makes payroll tax contributions a smaller share of earnings the higher are earnings above the ceiling.

Because the amount of consumption that can be financed out of earnings depends upon Social Security's net lifetime taxation and because the denominator in the DC tax-benefit rate is the household's level of consumption, the DC benefit rate will also be influenced by Social Security. In raising the lifetime consumption of the very poor, Social Security lowers their DC benefit rate. It does the opposite for those with higher incomes, especially for those who are in the middle class.

Taking into account the above-mentioned factors requires a life-cycle model that incorporates the.fine dețails of federal and state income taxation and Social Security taxes and benefits. It also requires a model that considers housing and special expenditures and recognizes household borrowing constraints. ${ }^{9}$ ESPlanner meets these requirements. Developed by Economic Security Planning, Inc., ESPlanner smoothes a household's living standard over its life cycle to the extent permitted by its capacity to borrow. As described in the Appendix, the program has highly precise federal and state income tax calculators and Social Security tax and benefit calculators. The income tax calculators determine whether households should itemize their deductions and

\footnotetext{
9 "Borrowing constrained" refers to a household's inability to get credit on the security of its future anticipated earnings, for example, through a credit card or an unsecured line of credit. "Liquidity constrained" often refers to that as well as to the inability to sell assets (whether financial or real) to finance consumption. The former term is more appropriate for the experiments considered in this paper.
} 
= place them in their appropriate tax brackets. They also properly deduct DC contributions and include DC - withdrawals in determining taxable income. ${ }^{10}$ The program also takes into account a variety of additional factors involved in life-cycle consumption planning, including the non-fungible nature of housing, bequest plans, and the desire of households to make special "off-the-top" expenditures on college tuition, etc. Finally, ESPlanner recognizes that a household's expenditures do not directly translate into its standard of living. Adjustments are made for household composition and household "economies of scale" -- the fact that people can live more cheaply together than apart. ${ }^{11}$ To be more precise, ESPlanner has a household provide for children until they reach age 19 , and considers that children may cost more or less than adults and that the relative costs of children can vary by age. It also adjusts for the number of adult equivalents based on a userspecified degree of economies to scale in shared living.

ESPlanner's principal outputs are recommended time-paths of consumption expenditure, taxable saving, and term-life insurance holdings (for each spouse in the case of married households). All outputs are displayed in current-year dollars. Consumption in this context is everything the household gets to spend after paying for its "off-the-top" expenditures - its housing expenses, special expenditures, life insurance premiums, taxes, and net contributions to tax-favored accounts. As mentioned, the amount of recommended consumption expenditures varies from year to year in response to changes in the household's composition. It also rises when the household moves from a situation of being borrowing constrained to one of being unconstrained. Finally, recommended household consumption will change over time if users intentionally specify that they want their living standard to change. For example, if users specify that they desire a 10 percent higher living standard after a certain year in the future, the software will incorporate that preference in making its recommendations, provided that it does not violate a borrowing constraint.

\footnotetext{
${ }^{10}$ See Gokhale, Kotlikoff and Warshawsky (2001, forthcoming) for a comparison of ESPlanner to more conventional retirement planning software.

${ }^{11}$ From the perspective of economic theory, the household is viewed as maximizing a Leontief intertemporal utility function with year-specific time preference and demographic weights subject to borrowing constraints and non-negativity constraints on life insurance.
} 
ESPlanner's recommended taxable saving in a particular year equals the household's total income (non-

- asset plus asset income) in that year minus that year's sum of (a) recommended spending on consumption and insurance premiums, (b) specified spending on housing and special expenditures, (c) taxes, and (d) net contributions to tax-favored accounts (contributions less withdrawals). Given the household's data inputs, preferences, and borrowing constraints, ESPlanner recommends the highest and smoothest possible living standard over time, leaving the household with zero terminal assets. ${ }^{12}$

Our strategy is to use ESPlanner to determine how much households should save in the absence of DC plans and then compare this recommended saving with the DC contribution limit. ESPlanner's recommended saving includes saving for education, saving for retirement, and saving to smooth the household's living standard prior to retirement. As indicated, ESPlanner considers a variety of key factors that influence actual saving decisions, but not all factors. The principal factor it ignores is uncertainty in earnings and rates of return. Hubbard, Skinner, and Zeldes (1995) is but one of a number of theoretical and simulation studies that show that earnings uncertainty can raise desired saving rates. Clearly then, optimal overall saving will be larger than saving recommended by ESPlanner.

\section{Are Statutory Limits on Contributions to Defined Contribution Plans Binding?}

Table 1 begins our evaluation of DC limits. It does so for a Massachusetts household that has no Social Security benefits, no children, no life-cycle earnings growth, no housing, and no DB plan or DC account. It also assumes that the household's total earnings, which range in the table from $\$ 25,000$ to $\$ 1$ million per year, are equally divided between spouses, that each spouse works to age 65 , that each spouse's maximum age of life is 95 , that the household has no assets at the age the household is being considered, and that the household earns a 4 percent real return on its savings. The household has no access to any non-secured borrowing, such as credit

\footnotetext{
12 ESPlanner's recommendations for annual term insurance are either positive or zero. If recommended term insurance is positive for a particular potential decedent (the household head or, if married, spouse) in a particular year and if the decedent dies at the end of that year, the surviving household will have precisely the same living standard as the household would have had absent the decedent's premature death. If the potential decedent's recommended insurance in a particular year is zero, the surviving household will have the same or higher living standard if the decedent dies in that year.
} 
card debt. The household's desired standard of living remains flat over the life cycle; this assumption is

- conservative for purposes of public policy analysis because it does not demand that the government help finance through tax benefits for retirement savings a continually rising standard of living.

We start with this highly unrealistic household to a) illustrate how ESPlanner works and b) make the strongest case that the statutory limits generally bind. That is, households with Social Security benefits, children, life-cycle earnings growth, and a mortgage to pay down will naturally save less when young.

In Table 1 and subsequent tables we consider two definitions of the household saving rate. The first is the "total" rate, by which we refer to total saving, including capital income, divided by total income, including capital income. The second is the "out-of-pocket" saving rate, which refers to total saving excluding capital income divided by total income, excluding capital income. The denominator in the out-of-pocket saving rate is simply current labor earnings, thus making it directly comparable to the 25 percent DC limit, which is also expressed relative to labor earnings. Table 1 considers households at various initial ages when they are assumed to have no assets. Therefore, they have no initial capital income and total and out-of-pocket saving rates are identical at these initial ages.

In this paper, we are somewhat informal in our characterization of poor, middle-income, upper-income, and so on because we are examining stylized households. One more formal frame of reference could come ERISA itself; federal law, for purposes of non-discrimination requirements applying to pension plans, defines the dividing line between highly compensated and non-highly-compensated workers to be (in 2001 ) $\$ 85,000$. This, of course, is for a single worker, not a household. Hence, we might characterize two-earner households with incomes of $\$ 150,000$ or less as non-highly-compensated, or not upper-income.

Table 1 delivers a number of messages. First, absent Social Security and with the other aforementioned factors, smoothing consumption requires a very high rate of saving. A middle-income $(\$ 50,000$ a year) couple needs to save 20.4 percent of its income at age 25 . If it fails to save and arrives at age 35 with no assets, it needs to save 27.0 percent of its income at that age. The corresponding saving rates at ages 45 and 55 are 36.6 
percent and 52.0 percent. Clearly, the 25 percent of earnings statutory DC joint employer-employee - contribution limit would bind for this household at ages 35,45 , and $55 .{ }^{13}$ This is the table's second message DC joint contribution limits are more likely to bind for older households who have engaged in little or no past saving. Indeed, the DC limits bind for all earnings classes at ages 35,45 , and 55 , but only for the two highest earning households at age 25. A third point is that appropriate life-cycle saving rates can vary considerably across households with different levels of earnings, particularly at older ages. The reason is the progressivity of income taxes, specifically the fact that higher earning households face relatively higher income taxes during their working years compared to their old age. This is particularly true of high earnings households who begin to accumulate wealth late in life.

Table 2 considers the same type of households, but now assumes that the households properly save for their retirement as they age, so that when we consider them, they hold assets equal to the accumulated amounts should have saved in the past. As a comparison with Table 1 indicates, this makes a huge difference to the rate at which the households need to save late in life. For example, households at 55 who earn $\$ 25,000$ per year need to save only 30.9 percent of their wages, if they have saved in the past, compared to 54.5 percent if they haven't.

Proper saving over the life cycle dramatically reduces the potential for hitting the DC contribution limit. Table 3 shows the out-of-pocket saving rates that correspond to the total saving rates in Table 2; these are the rates directly relevant to the evaluation of contribution limits. The statutory DC joint employee-employer contribution limit now binds in none of the cells, except at age 25 for the household earning $\$ 300,000$ per year and at ages 25,35 , and 45 for the household earning $\$ 1$ million per year. The limit on employee elective contributions would, however, constrain optimal contributions at earlier ages among the middle income as well as the upper income groups in the case of workers whose employers contribute little or nothing on their behalf.

\footnotetext{
${ }^{13}$ The fact that this saving would be done in tax-favored form wouldn't change this statement. The tax benefits would raise recommended consumption when young and old, but also lower taxes when young and raise them when old. The net impact would be more disposable income when young. Hence, if the household can save $x$ percent when young in non tax-favored form without being liquidity constrained, it can save an even higher percent in tax-favored form when young without being constrained.
} 
The comparison of Tables 2 and 3 indicates how much of a household's required life-cycle saving can

- be achieved in middle age by simply saving the capital income one earns on past saving. Compare, for example, the 23.1 percent total saving rate recommended in Table 2 for a 55 year-old household earning $\$ 150,000$ with the corresponding 0.3 percent out-of-pocket rate in Table 3 . For this household, there is almost no need to actively save out of earnings at this age to smooth its future living standard. All the household needs to do is reinvest its capital income. For households with even higher earnings, the recommended out-of-pocket saving rates are slightly negative. The clear message of Table 3 is that for the types of households we are examining who do their homework and save early in life, the DC limits will not bind unless the household has unusually high labor earnings when young or has an employer that makes little or no contributions on' the workers' behalf.

Table 4 turns to a more realistic set of households. In the new set of households the real earnings of both the husband and wife grow by 1 percent per year each year prior to retirement. The households own their homes, have two children, and pay Social Security taxes and receive Social Security benefits. The first child is born when the couple is age 25 , and the second when the couple is age 30 . The market value of a couple's house is set at three times annual labor earnings as of age 25 . The couple is assumed to purchase its house at age 25 , to borrow at 8 percent, put 20 percent down, and to take out a 30-year mortgage. Annual homeowner's insurance, property taxes, and maintenance are set at .17 percent, 1 percent, and 1 percent of house value, respectively. Each child is assumed to attend college for four years. A couple earning $\$ 25,000$ per year is assumed to spend $\$ 7,500$ per child for each year of college. This college expense is set at $\$ 15,000$ for couples earning $\$ 50,000$ and $\$ 30,000$ for couples earning $\$ 100,000$ or $\$ 150,000$. For couples earning $\$ 200,000$ or more per year, annual college expenses are capped at $\$ 35,000$. Non-secured borrowing is constrained to zero, as in the simple cases above. Also as in the prior tables, we continue to assume that the household does not participate in a defined contribution plan.

Table 4 has four panels that differ with respect to the ages at which the household begins saving. For example, panel $4 c$ assumes the household begins saving at age 45 and, therefore, had no accumulated savings as 
of age 45. Each panel shows the total and out-of-pocket saving rates at the age when the household begins to - save and at subsequent ages. Consider first panel $4 \mathrm{a}$, which examines the household at age 25 . The table shows zero recommended saving at age 25 , negative recommended saving at age 30 , low recommended saving at age 35 , modest recommended saving at age 40 , negative recommended saving at ages 45 and 50 (except for the top earning households) and high recommended saving at ages 55 and 60 . What's going on here? The answer is that the household is borrowing constrained when it starts out and then does some small saving prior to the arrival of the second child. These savings are spent down when the second child arrives. Between ages 25 and 40 the household is spending much of its resources paying down its mortgage. Once the real value of these mortgage payments is lowered by the assumed annual 3 percent inflation, the household begins to save for its children's college education. At ages 45 and 50 the children are in college, and we see the household dissaving as it meets tuition payments. Once the children have completed college the household can begin saving in earnest for retirement. Consider the $\$ 50,000$ per year household: its recommended out-of-pocket saving rates at age 55 and age 60 are both a substantial 19.4 percent.

This recommended life-cycle saving pattern may seem surprising, but it corresponds to what one observes empirically. As shown in Kotlikoff and Summers (1981), Gokhale, Kotlikoff, and Sabelhaus (1996), and Carroll and Summers (1991), longitudinal age-consumption and age-earnings profiles track each other very closely before late middle age, so that the hump saving that does occur, occurs only in the 15 or so years before retirement.

In panel 4a we indicate with an asterisk cells in which the households would not be able to do all of its recommended saving via a defined contribution plan, assuming the plan permitted the maximum allowable combined employer-employee contribution. As shown, the constraints only bind for the top two earning households, and only in middle and late middle age. We indicate with italics cells in which the households would not be able to do all of their recommended saving if their employers made no contributions to their plans and they were limited by the elective (individual) contribution limit. The elective contribution limit also binds only at older ages, but across a wider range of earnings. 
In addition to the interesting pattern of recommended saving rates by age, panel 4a shows remarkable variation at a given age across households with different levels of earnings. At age 55, the $\$ 25,000$-a-year earning household needs to save 15.6 percent of its income to smooth its future living standard. In contrast, the $\$ 150,000$-a-year earning household needs to save 24.3 percent of its income. What explains the difference? The answer, for the most part, is Social Security, which replaces a much larger share of the lower income household's earnings.

Panel $4 \mathrm{~b}$ repeats the exercise, but considers the household at age 35 under the assumption that the household failed to save in the past. The sign pattern of recommended saving rates from age 35 onward is similar to that in panel $4 \mathrm{a}$, but the magnitudes of recommended saving rates are somewhat different. For example, in panel $4 \mathrm{a}$, the recommended out-of-pocket saving rate for the $\$ 50,000$-a-year earning household at age 40 is 4.8 percent compared with 5.8 percent in panel $4 \mathrm{~b}$. If the households wait even later, until age 45 to start saving, the saving rates are quite different, as shown in panel 4c. Now the recommended age-45 saving rates are zero, except for the highest earning household. The reason is that these households, because they have no assets, need to spend every free dollar on college tuition and mortgage payments. That is, they are borrowing constrained and do the best they can do, which in this case is to save nothing. Once their children are out of college, saving picks up, but at a generally lower rate than had the household started saving before age 45 . Waiting until later in life to save doesn't alter significantly the number of cells that violate the DC limits.

\section{$\underline{\text { Sensitivity Analysis }}$}

Although we believe the set of households we examined in Table 4 are closer to reality than the initial cases we examined, they are still highly idealized. They represent a remarkable degree of earnings stability and equality over a long horizon. In particular, the assumption of long and equal labor force participation at a steadily growing wage by husband and wife, both implicitly having access to the opportunity to save through a pension plan, is still an unusual occurrence. Hence, we believe for policy analysis purposes, the sensitivity analysis in Table 5 will be particularly relevant. 
Table 5 makes alternative assumptions in recalculating out-of-pocket saving rates at ages 35,45 , and 55 - assuming the households saved appropriately in the past. The alternative assumptions include a 6 rather than a 4 percent real return, extra initial assets equal to one year's earnings at age 25 , no second child, maximum age of life of 100, 2 rather than 1 percent real growth in earnings, and retirement at age 60 . Other alternative assumptions include no borrowing constraint, the decision by the wife to remain at home while the children are young, and residence in Indiana rather than Massachusetts. A final set of alternative assumptions include a) a two-third-one-third, rather than a fifty-fifty, split of earnings between the husband and wife, b) the husband earning all household income, and c) a desired 1 percent annual growth in the household's standard of living through age 65 .

A quick glance through the three panels of Table 5 indicates that the variants of 2 percent growth in wages, no borrowing constraint, and early retirement make the greatest difference to recommended saving rates. DC joint employee-employer contribution limits bind more frequently in these cases as well as those in which one spouse accounts for most of the household's earnings. However, with the exception of the early retirement scenario and the no-borrowing constraint cases in panel $5 \mathrm{c}$, all the cells in which the joint employee-employer contribution limit binds involve older, upper-income households.

With higher real wage growth, households are borrowing constrained for longer periods of time and recommended saving at age 35 is zero. At age 45 , recommended dissaving rates are roughly half as large, in absolute value, for the low and middle earning households than in the base case. Because households experiencing higher earnings growth are borrowing constrained for longer periods of time, their capacity to save and their subsequent ability to dissave, when children enter college, are both diminished. The absence of borrowing constraints leads the lowest five earning households to dissave at both ages 35 and 45 . These households then choose to save at dramatically higher rates at age 55. Indeed, households at every level of earnings, who can borrow freely, are subject to the joint DC contribution limits at age 55 . When there is no borrowing constraint, the household borrows extensively early in the life cycle. In order to repay these debts and to fund retirement, it must increase its savings rate substantially when older. 
Households that retire early have fewer years to prepare for retirement and longer retirements to finance,

- which explains why they save at higher rates while working. Although allocating most or all of a household's earnings to one spouse doesn't change recommended saving rates very much, it does change the dollar limit applied to the household's total DC contribution. With two earnings, the limit is $\$ 60,000$, but with only one earner, it is only $\$ 30,000$. This explains why more of the cells in Table 5 under these variants would be bound by the contribution limits.

The other variants make relatively little difference to recommended saving rates. Consider, for example, the case of no second child. Table 5(a) shows that saving rates at age 35 are lower for low-income households, but higher for high income ones. The elimination of future college costs increases a low-income household's sustainable consumption level by enough to make it borrowing constrained when young. At middle and upper income levels the opposite happens because college costs do not rise in proportion to lifetime income. With one less child, borrowing constraints no longer bind at age 35 because the increase in sustainable consumption due to lower college expenses is less than the reduction in one child's consumption expenses when young. Thus, middle- and upper-income households save more at age 35 compared to the base case. Table 5(b) shows that, at age 45 , saving rates are higher (less negative) at all income levels because one fewer child implies smaller current college expenses. Table 5(c) shows that saving rates at age 55 are lower at all income levels because, with one fewer child, more saving has been done earlier in life.

When the household desires a rising, rather than a flat, standard of living during their working years, the out-of-pocket saving rate is higher in early years, lower in the middle years when children go to school,- and significantly higher for middle-income households in the years preceding retirement. But these changes in saving rates don't change the conclusion that the DC joint limits aren't binding except for older, upper-income households.

\section{The Impact of Participating in DC Plans on the Age-Consumption Profile}


Because most of our households are borrowing constrained at young ages, participating at any level in a - DC plan comes at the price of suffering a decline in current relative to future living standards. Tables 6 and 7 show that contributing even small percentages of wages to DC plans can have a large impact on relative consumption when young and old. Table 6's calculations assume a 4 percent real return, while Table 7's assume a 7 percent real return. Both tables focus on the household that earns $\$ 50,000$ per year.

Consider first Table 6's results for the Base Case with no contribution to a DC plan. The first column shows the Base Case with borrowing constraints; the second shows the Base Case with no borrowing constraints. In the absence of borrowing constraints, the household enjoys the same living standard each year, but its consumption expenditure varies with the size of the household. In the presence of borrowing constraints, the profile of the household's living standard is disjoint, although it is smoothed to the maximum extent possible. The first two columns of Table 6 show that consumption is 17 percent lower at age 25 , and 25 percent higher in the final year when the borrowing constraint in imposed than when it is not.

Consider next how a 10 percent contribution to a DC plan affects these results at age 25 . Consumption at age 25 under the borrowing constraint is one third less than it would be with no borrowing constraints. At the end of the household's life, it is a remarkable 71 percent greater. Stated differently, with the 10 percent contribution and in the presence of borrowing constraints, consumption expenditures at the end of life are more than twice as large as they are at the beginning. In contrast, when the household is not borrowing constrained, it consumes 18 percent less when old than when age 25 .

These results are magnified if the DC contribution rate is 25 , rather than 10 , percent of earnings. Now in the borrowing constrained case, consumption when old is almost 5 times its level when young. Next consider what happens (in Table 7) if the borrowing-constrained household earns 7 percent rather than 4 percent real on both their non-DC and DC assets. In this case, consumption when old is almost 4 times its value when age 25 when the contribution rate is 10 percent. If the contribution rate is 25 percent, consumption when young is half of what it would be were the household not borrowing constrained, and consumption when old is almost 10 times as high as the amount spent when young! The most telling comparison here is between the levels of 
consumption at age 25 in this case, in which contributions are set at the legal maximum, and in the base case, in

- which there are no DC contributions. Consumption in this case is roughly one third less than in the base case.

Hence, in order to contribute up to the statutory ceiling, the household would have to be willing to lower its immediate living standard by one third - a sacrifice that most young households would appear to be unwilling to make.

\section{The Size of the DC Tax Benefit}

By comparing, for different rates of DC contributions, the levels of consumption in the non-borrowing constrained cases in Tables 6 and 7 one can automatically see the tax advantage of participating in a DC plan. Table 8 presents the DC benefit for different rates of return under the assumption that the real rates of return on non-DC assets and DC assets are the same. It captures the pure tax advantage to contributing to a DC plan. To examine the potential benefit afforded by DC plans, the calculations assume elective employee contributions and employer matching contributions equal to the average of maximum contributions allowed across DC plans. The household's elective contribution is set at 13.5 percent of earnings and the employer-matching contribution is set at 3 percent of earnings, bringing the total DC plan contribution to 16.5 percent of earnings. ${ }^{14}$

Table 8 shows that at a 4 percent return, the lifetime tax benefit from consistently participating in a DC plan increases from 1.9 percent at household earnings of $\$ 25,000$ to 3.5 percent at $\$ 100,000$, and to 9.8 percent at $\$ 300,000$. The dollar limit on contributions reduces the subsidy to 7.7 percent at earnings of $\$ 1,000,000$. At a 6 percent real return, the poor and low-income classes get a small tax break, while the high income households continue to receive significant benefits. At an even higher, 8 percent real return, poor and lowincome households actually lose from 1.5 to 1.9 percent of their lifetime consumption from participating in a DC plan as the result of ending up in higher tax brackets in retirement. Even those earning $\$ 100,000$ a year end up slightly worse off from participating. In contrast, households with earnings of $\$ 1$ million per year enjoy a

\footnotetext{
${ }^{14}$ At this contribution rate, the dollar contribution ceiling limits the household's contribution to $\$ 60,000$ at earnings exceeding of $\$ 363,636.36$. In our actual use of ESPlanner to make these calculations we treat all contributions as made by the employee so that when we run the same case without DC contributions, there is no difference in the gross income earned by the workers.
} 
tax benefit equal to 6.5 percent of their lifetime consumption. Clearly, there are large gains and also a few nontrivial losses to be had by contributing to DC plans. The table also shows that the tax benefit to DC plans is regressive.

\section{Summary and Conclusion}

Our central findings are four. First, for households that engage in life-cycle saving and have Social Security benefits, children, housing, and modest life-cycle earnings growth, joint employer-employee DC contribution limits would bind only for those with very high levels of earnings. However, the elective employee contribution limit would bind across a wider range of earnings if employers were to make no DC contributions on behalf of their employees. Second, the DC limits will bind for middle-class as well as upperincome households at older ages if these households fail to save when young, plan to retire early, are single earners, are not borrowing constrained, or experience rapid real wage growth. Third, given borrowing constraints, participating in DC plans comes at the cost of reducing one's consumption when young dramatically compared to what one will consume when old. For example, assuming a 10 percent contribution rate and a 4 percent real return, our stylized household's consumption in retirement is almost twice its value when young. Fourth, assuming moderate rates of return, all income classes benefit from participating in DC plans, although the tax break as a percent of lifetime consumption is higher for those with high incomes. At these rates of return, the statutory limit on joint contributions is effective in lowering the subsidy rate to the rich. However, at much higher rates of return, participating in DC plans actually generates higher lifetime net taxes for low- and middle-income households because it pushes them into higher marginal tax brackets.

At most income levels and rates of return, tax breaks from DC plan-participation can be significant. But the receipt of these tax breaks is only available to those fortunate enough to work for employers that offer DC plans with high contribution rates. Taking advantage of the DC tax break, when it exists, requires not only finding the right employer, but also, in many cases, being willing to forego some current consumption in order to enjoy higher consumption in old age. For the middle-income stylized household we considered here, 
participating in a DC plan that sets contributions at the statutory limit and earns a 4 percent real return means

- spending almost four times more on consumption when old than when young.

ERISA doesn't delineate principles for setting DC contribution limits. It doesn't say, for example, that households with specific incomes should be able to save enough in tax-deferred form to finance fully their retirements. In focusing on benefit security, rather than saving adequacy, Congress appears to have set ERISA's contribution limits primarily based on equity and revenue considerations. ${ }^{15}$ Had Congress instead tried to establish lifetime, rather than annual, contribution limits to achieve a particular retirement saving target, it would have had a difficult time. As demonstrated here, the right target is critically dependent on a range of household-specific demographic and economic factors. In addition, regulating lifetime contribution limits would be more difficult administratively than regulating annual ones.

If, in the context of our current income-tax structure, annual retirement account contribution limits represents the only practical approach, what principles should guide the setting of these limits? We offer four. The first is equal treatment of workers no matter their choice of employer. This could be accomplished by allowing workers to make IRA contributions equal to the difference between the DC statutory limits and the maximum joint elective and employer contribution permitted by their DC plans. ${ }^{16}$ If this first principle could not be honored, a second, less ambitious one is equal treatment of all workers participating in DC plans, regardless of their choice of employer. This could be achieved by allowing workers to make elective contributions equal to the difference between the DC statutory limits and the employer's contribution on the worker's behalf. A third principal would be that older workers need more scope to save for their retirement than do younger ones. This principle recognizes that many, if not most, households are liquidity constrained when young and will be able to do significant retirement saving only in the fifteen or so years prior to retirement. A fourth principle is that the tax breaks afforded to DC participants not be viewed in isolation, but

\footnotetext{
${ }^{15}$ This criterion for setting limits can be contrasted with state-sponsored Section 529 tuition savings plans. There the law is explicit that the policy goal is to enable families to pay for five years of tuition and other educational expenses at the most expensive college included in the plan, and that the state sponsor is to set lifetime contribution limits to allow the achievement of that goal (see Ma, et. al., 2000).

${ }^{16}$ Thus, workers with no DC plan would be able to contribute this year the lesser of 25 percent of their earnings or $\$ 30,000$ to an IRA.
} 
- rather set against the advantages certain households obtain from Social Security, Medicare, and other - government tax-transfer programs. Meeting all four principles in establishing public policy requires a careful balancing of equity and administrative concerns. 


\section{References}

B. Douglas Bernheim, Lorenzo Forni, Jagadeesh Gokhale, and Laurence J. Kotlikoff, "How Much Should Americans Save for Retirement?" The American Economic Review, May 2000.

Bureau of Labor Statistics, Employee Benefits in Medium and Large Private Establishments, 1997, September 1999.

Carroll, Chris and Lawrence H. Summers, "Consumption Growth Parallels Income Growth: Some New Evidence," in National Saving and Economic Performance, eds. B. Douglas Bernheim and John Shoven. Chicago: The University of Chicago Press, 1991. Pp. 305-343.

Employee Benefit Research Institute, EBRI Databook on Employee Benefits, Fourth Edition, 1997.

Gokhale, Jagadeesh, Laurence J. Kotlikoff, and John Sabelhaus, "Understanding the Postwar Decline in United States Saving: A Cohort Analysis," The Brookings Papers on Economic Activity, 1996.

Gokhale, Jagadeesh, Laurence J. Kotlikoff, and Mark J. Warshawsky, "Comparing the Economic and Conventional Approaches to Financial Planning," in Laurence J. Kotlikoff, Essays on Saving, Bequests, and Altruism, Cambridge, MA: MIT Press, 2001, forthcoming.

Hubbard, R. Glenn, Jonathan Skinner, and Stephen Zeldes, "Precautionary Saving and Social Insurance," Journal of Political Economy, April 1995.

Kotlikoff, Laurence J. and Lawrence H. Summers, "The Role of Intergenerational Transfers in Aggregate Capital Formation," The Journal of Political Economy, August 1981.

Ma, Jennifer, Mark J. Warshawsky, John Ameriks, and Julia Blohm "An Economic Approach to Setting the Contribution Limits to Qualified State-sponsored Tuition Savings Programs," TIAA-CREF Institute Working Paper, June 2000.

Poterba, James, Steven Venti, and David Wise, "Do 401k Contributions Crowd Out Other Private Saving?" Journal of Public Economics, vol. 58, 1995, pp. 1-32.

, "401k Plans and Tax-Deferred Saving," in Economics of Aging, David A. Wise. ed., University of Chicago Press, 1994, pp. 105-138.

"The Effects of Special Saving Programs on Saving and Wealth," in The Economic Effects of Aging in the United States and Japan, Michael D. Hurd and Naohiro Yashiro, eds., pp. 217-240, Chicago: University of Chicago Press, 1997.

working paper no. 6295, March 1999.

, "Implications of Rising Personal Retirement Saving," NBER

Warshawsky, Mark J. and John Ameriks, "How Prepared Are Americans for Retirement?" in Olivia S. Mitchell, P. Brett Hammond, and Anna Rappaport, editors, Forecasting Retirement Needs and Retirement Wealth,

Pension Research Council, Philadelphia: University of Pennsylvania Press, 2000, pp. 33 - 67. 
Chart 1

Contribution Limits to DC Plans: Nominal and Inflation-Adjusted

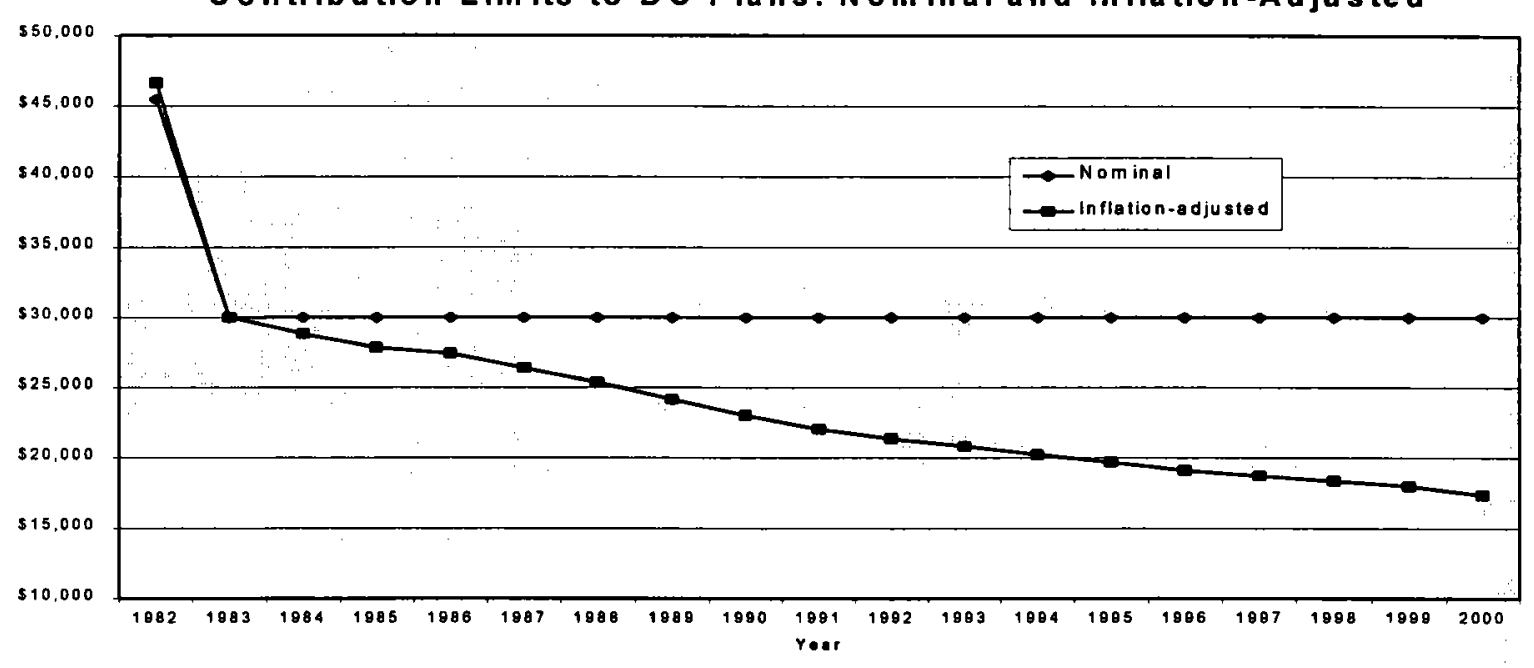


Table 1

Total as Well as Out-of-Pocket Saving Rates by Age and Annual Earnings with No Initial Assets (Married Couple with No Children, No Social Security Benefits, No Earnings Growth, and No Housing)

Age

\begin{tabular}{|l|c|c|c|c|c|}
\hline \multicolumn{1}{|c|}{ Earnings } & $\mathbf{2 5}$ & $\mathbf{3 5}$ & $\mathbf{4 5}$ & $\mathbf{5 5}$ & $\begin{array}{c}\text { Maximum DC } \\
\text { Contribution Rate }\end{array}$ \\
\hline $\mathbf{\$ 2 5 , 0 0 0}$ & 19.4 & 26.7 & 37.0 & 54.5 & 25.0 \\
\hline $\mathbf{\$ 5 0 , 0 0 0}$ & 20.3 & 27.0 & 36.6 & 52.0 & 25.0 \\
\hline $\mathbf{\$ 1 0 0 , 0 0 0}$ & 20.4 & 26.3 & 34.6 & 48.1 & 25.0 \\
\hline $\mathbf{\$ 1 5 0 , 0 0 0}$ & 20.8 & 26.2 & 33.7 & 46.1 & 25.0 \\
\hline $\mathbf{\$ 2 0 0 , 0 0 0}$ & 20.7 & 29.0 & 35.8 & 46.7 & 25.0 \\
\hline $\mathbf{\$ 2 5 0 , 0 0 0}$ & 20.5 & 25.4 & 32.4 & 43.5 & 24.0 \\
\hline $\mathbf{\$ 3 0 0 , 0 0 0}$ & 20.3 & 27.9 & 34.3 & 44.4 & 20.0 \\
\hline $\mathbf{\$ 1 , 0 0 0 , 0 0 0}$ & 19.3 & 23.8 & 29.8 & 39.2 & 6.0 \\
\hline
\end{tabular}

The total saving rate is defined as total saving divided by total income. The out-of-pocket saving rate is defined as a) total saving minus capital income divided by b) total labor earnings.

Table 2

Total Saving Rates by Age and Annual Earnings with Life-Cycle Assets (Married Couple with No Children, No Social Security Benefits, No Earnings Growth, and No Housing) Age

\begin{tabular}{|l|c|c|c|c|}
\hline \multicolumn{1}{|c|}{ Earnings } & $\mathbf{2 5}$ & $\mathbf{3 5}$ & $\mathbf{4 5}$ & $\mathbf{5 5}$ \\
\hline $\mathbf{\$ 2 5 , 0 0 0}$ & 19.4 & 23.2 & 27.1 & 30.9 \\
\hline $\mathbf{\$ 5 0 , 0 0 0}$ & 20.3 & 24.1 & 26.3 & 27.7 \\
\hline $\mathbf{\$ 1 0 0 , 0 0 0}$ & 20.4 & 22.3 & 23.8 & 24.9 \\
\hline $\mathbf{\$ 1 5 0 , 0 0 0}$ & 20.8 & 22.3 & 22.9 & 23.1 \\
\hline $\mathbf{\$ 2 0 0 , 0 0 0}$ & 20.7 & 21.2 & 21.7 & 22.0 \\
\hline $\mathbf{\$ 2 5 0 , 0 0 0}$ & 20.5 & 21.1 & 21.4 & 21.4 \\
\hline $\mathbf{\$ 3 0 0 , 0 0 0}$ & 20.3 & 20.6 & 20.8 & 21.0 \\
\hline $\mathbf{\$ 1 , 0 0 0 , 0 0 0}$ & 19.3 & 19.8 & 20.1 & 20.3 \\
\hline
\end{tabular}


Table 3

Out-of-Pocket Saving Rates by Age and Annual Earnings with Life-Cycle Assets

(Married Couple with No Children, No Social Security Benefits, No Earnings Growth, and No Housing)

\begin{tabular}{|l|c|c|c|c|c|}
\hline \multicolumn{1}{|c|}{ Age } \\
\hline $\mathbf{\$ 2 5 , 0 0 0}$ & $\mathbf{2 5}$ & $\mathbf{3 5}$ & $\mathbf{4 5}$ & $\mathbf{5 5}$ & $\begin{array}{c}\text { Maximum DC } \\
\text { Contribution Rate }\end{array}$ \\
\hline $\mathbf{\$ 5 0 , 0 0 0}$ & 19.4 & 16.6 & 12.9 & 7.8 & 25.0 \\
\hline $\mathbf{\$ 1 0 0 , 0 0 0}$ & 20.3 & 17.3 & 11.5 & 3.7 & 25.0 \\
\hline $\mathbf{\$ 1 5 0 , 0 0 0}$ & 20.4 & 15.6 & 9.6 & 2.0 & 25.0 \\
\hline $\mathbf{\$ 2 0 0 , 0 0 0}$ & 20.8 & 15.5 & $\mathbf{8 . 9}$ & .3 & 25.0 \\
\hline $\mathbf{\$ 2 5 0 , 0 0 0}$ & 20.7 & 14.6 & 7.7 & 0.0 & 25.0 \\
\hline $\mathbf{\$ 3 0 0 , 0 0 0}$ & 20.5 & 14.5 & 7.4 & -.4 & 24.0 \\
\hline $\mathbf{\$ 1 , 0 0 0 , 0 0 0}$ & 20.3 & 14.1 & 7.2 & -.5 & 20.0 \\
\hline
\end{tabular}


Table 4

Total as Well as Out-of-Pocket Saving Rates by Age and Annual Earnings with No Initial Assets at Age when Saving Begins

(Married Couple with Two Children, Social Security Benefits, Increasing Earnings, and a House)

a) Saving begins at age 25

\begin{tabular}{|c|c|c|c|c|c|c|c|c|c|}
\hline & & & ge & & & & & & \\
\hline $\begin{array}{c}\text { Earnings at } \\
\text { Age } 25\end{array}$ & $\begin{array}{l}\text { Type of } \\
\text { Savings }\end{array}$ & 25 & 30 & 35 & 40 & 45 & 50 & 55 & 60 \\
\hline & Total & $\overline{0}$ & -3.1 & .1 & 6.1 & -8.9 & -2.9 & $\overline{15.6}$ & 20.0 \\
\hline$\$ 25,000$ & Out-of-Pocket & 0 & -3.1 & .1 & 5.6 & -10.0 & -3.1 & 15.0 & 16.9 \\
\hline 550000 & Total & 0 & -2.8 & .2 & 5.2 & -8.7 & -3.1 & 20.2 & $\overline{23.2}$ \\
\hline$\$ S 0,000$ & Out-of-Pocket & 0 & -3.0 & .2 & 4.8 & -9.7 & -3.3 & $19 . \overline{4}$ & 19.4 \\
\hline$\$ 100000$ & Total & $\overline{0}$ & -2.7 & 1.5 & $\overline{5.5}$ & -10.1 & -3.2 & 21.8 & 24.6 \\
\hline 3100,000 & Out-of-Pocket & 0 & -2.9 & 1.5 & 4.9 & -11.4 & -3.5 & 20.9 & 20.5 \\
\hline & Total & $\overline{0}$ & -2.4 & $\overline{0}$ & 2.5 & -4.4 &.- .2 & 24.3 & 26.3 \\
\hline$\$ 150,000$ & Out-of-Pocket & 0 & -2.6 & 0 & 2.4 & -4.9 & -.4 & 23.2 & 21.6 \\
\hline & Total & $\overline{0}$ & -2.8 & $\overline{0}$ & 1.9 & -3.3 & 5.7 & $\overline{26.7}$ & $\overline{28.1}$ \\
\hline$\$ 200,000$ & Out-of-Pocket & 0 & -3.0 & 0 & 1.8 & -3.7 & 5.1 & $24.6^{*}$ & $22.2^{*}$ \\
\hline & Total & $\overline{0}$ & -2.8 & 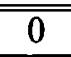 & 2.8 & $\overline{.4}$ & 9.5 & 27.3 & $\overline{28.4}$ \\
\hline$\$ 250,000$ & Out-of-Pocket & 0 & -3.0 & 0 & 2.6 & -.3 & 8.1 & $24.1^{*}$ & $21.4^{*}$ \\
\hline & Total & $\overline{0}$ & -2.9 & $\overline{\overline{0}}$ & 3.7 & 3.1 & 11.6 & 27.6 & $\overline{28.5}$ \\
\hline$\$ 300,000$ & Out-of-Pocket & 0 & -3.0 & 0 & 3.4 & 2.1 & 9.5 & $23.7^{*}$ & $20.8^{*}$ \\
\hline & Total & 0 & -1.2 & 3.3 & 6.9 & 12.0 & 19.2 & 28.5 & 29.2 \\
\hline$\$ 1,000,000$ & Out-of-Pocket & 0 & -1.6 & 2.8 & $5.6^{*}$ & $9.4^{*}$ & $14.6^{*}$ & $21.7^{*}$ & $18.5^{*}$ \\
\hline
\end{tabular}

The total saving rate is defined as total saving divided by total income. The out-of-pocket saving rate is defined as a) total saving minus capital income divided by $b$ ) total labor earnings.

* Desired saving would be restricted by a maximum DC contribution rate of $25 \%$ or combined total contribution of $\$ 60,000$.

Italics Desired saving would be restricted by a elective contribution limit of $\$ 10,500$ were the employer to make no contributions to the plan. 
Table 4 continued

Total as Well as Out-of-Pocket Saving Rates by Age and Annual Earnings with No Initial Assets at Áge when Saving Begins

(Married Couple with Two Children, Social Security Benefits, Increasing Earnings, and a house)

b) Saving begins at age 35

\begin{tabular}{|c|c|c|c|c|c|c|c|}
\hline \multicolumn{8}{|c|}{ Age } \\
\hline $\begin{array}{c}\text { Earnings at } \\
\text { Age } 35\end{array}$ & $\begin{array}{l}\text { Type of } \\
\text { Savings }\end{array}$ & 35 & 40 & 45 & 50 & 55 & 60 \\
\hline \multirow{2}{*}{$\$ 25,000$} & Total & 2.1 & 4.9 & -11.6 & -3.6 & 14.5 & 19.0 \\
\hline & Out-of-Pocket & 2.1 & 4.1 & -13.1 & -3.9 & 14.3 & 16.2 \\
\hline \multirow{2}{*}{$\$ 50,000$} & Total & .4 & $\overline{6.3}$ & $\overline{-10.4}$ & -3.7 & 19.2 & 22.3 \\
\hline & Out-of-Pocket & .4 & 5.8 & -11.8 & -4.0 & 18.7 & 18.7 \\
\hline \multirow{2}{*}{$\$ 100,000$} & Total & 1.4 & $\overline{66.5}$ & -11.5 & -3.9 & 21.4 & 24.3 \\
\hline & Out-of-Pocket & 1.4 & 5.9 & -12.9 & -4.3 & 20.7 & 20.3 \\
\hline \multirow{2}{*}{$\$ 150,000$} & Total & $\overline{0} 0$ & 3.2 & -5.5 & -2.0 & 24.7 & $26 . \overline{8}$ \\
\hline & Out-of-Pocket & 0 & 3.1 & -6.1 & -2.2 & 23.8 & 22.3 \\
\hline \multirow{2}{*}{$\$ 200,000$} & Total & 0 & 2.2 & -4.1 & 2.4 & 27.4 & $29 . \overline{1}$ \\
\hline & Out-of-Pocket & 0 & 2.2 & -4.5 & 2.0 & $25.9^{*}$ & $23.7^{*}$ \\
\hline \multirow{2}{*}{$\$ 250,000$} & Total & $\overline{0}$ & 1.0 & -2.2 & $\overline{6.9}$ & 28.6 & $29 . \overline{7}$ \\
\hline & Out-of-Pocket & 0 & 1.0 & -2.4 & 6.2 & $26.4^{*}$ & $23.6^{*}$ \\
\hline \multirow{2}{*}{$\$ 300,000$} & Total & $\overline{0}$ & 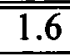 & .6 & $\overline{9.4}$ & 28.8 & 29.8 \\
\hline & Out-of-Pocket & 0 & 1.5 & .1 & 8.2 & $25.9^{*}$ & $23.1^{*}$ \\
\hline \multirow{2}{*}{$\$ 1,000,000$} & Total & 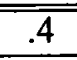 & 5.0 & 10.2 & 17.4 & 29.7 & 30.5 \\
\hline & Out-of-Pocket & .4 & 4.6 & $8.6^{*}$ & $14.0^{*}$ & $24.3^{*}$ & $21.0^{*}$ \\
\hline
\end{tabular}

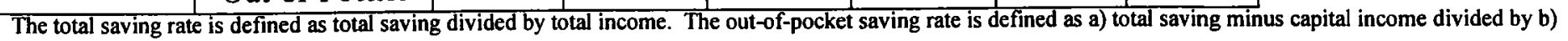
total labor earnings.

* Desired saving would be restricted by a maximum DC contribution rate of $25 \%$ or combined total contribution of $\$ 60,000$.

Italics Desired saving would be restricted by a elective contribution limit of $\$ 10,500$ were the employer to make no contributions to the plan. 
Table 4 continued

Total as Well as Out-of-Pocket Saving Rates by Age and Annual Earnings with No Initial Assets at Age when Saving Begins

(Married Couple with Two Children, Social Security Benefits, Increasing Earnings, and a house)

c) Saving begins at age 45

\begin{tabular}{|c|c|c|c|c|c|}
\hline \multicolumn{6}{|c|}{ Age } \\
\hline $\begin{array}{c}\text { Earnings at } \\
\text { Age 45 } \\
\end{array}$ & $\begin{array}{l}\text { Type of } \\
\text { Savings } \\
\end{array}$ & 45 & 50 & 55 & 60 \\
\hline \multirow{2}{*}{$\$ 25,000$} & Total & 0 & -4.6 & 6.3 & 9.9 \\
\hline & Out-of-Pocket & 0 & -5.0 & 6.3 & 8.6 \\
\hline \multirow{2}{*}{$\$ 550,000$} & Total & 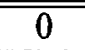 & -4.4 & 12.5 & $\overline{15.9}$ \\
\hline & Out-of-Pocket & 0 & -4.8 & 12.5 & 13.6 \\
\hline \multirow{2}{*}{$\$ 100,000$} & Total & $\overline{0}$ & -4.6 & 19.7 & $\overline{22.6}$ \\
\hline & Out-of-Pocket & 0 & -5.1 & 19.3 & 19.2 \\
\hline \multirow{2}{*}{$\$ 150,000$} & Total & 0 & -2.4 & 23.4 & $\overline{25.7}$ \\
\hline & Out-of-Pocket & 0 & -2.6 & 22.7 & 21.6 \\
\hline \multirow{2}{*}{$\$ 200,000$} & Total & 0 & -1.9 & 27.6 & 29.3 \\
\hline & Out-of-Pocket & 0 & -2.0 & $26.8^{*}$ & 24.7 \\
\hline \multirow{2}{*}{$\$ 250,000$} & Total & $\overline{0}$ & 2.6 & 28.9 & 30.5 \\
\hline & Out-of-Pocket & 0 & 2.2 & $27.5^{*}$ & $25.2^{*}$ \\
\hline \multirow{2}{*}{$\$ 300,000$} & Total & 0 & 5.5 & 29.6 & 30.9 \\
\hline & Out-of-Pocket & 0 & 5.0 & $27.8^{*}$ & $25.2^{*}$ \\
\hline \multirow{2}{*}{$\$ 1,000,000$} & Total & $\overline{7.3}$ & 14.9 & 31.4 & $\overline{32.3}$ \\
\hline & Out-of-Pocket & $7.3^{*}$ & $13.2^{*}$ & $27.9^{*}$ & $24.6^{*}$ \\
\hline
\end{tabular}

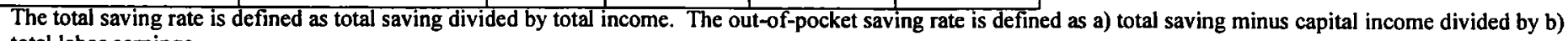
total labor earnings.

- Desired saving would be restricted by a maximum DC contribution rate of $25 \%$ or combined total contribution of $\$ 60,000$.

Italics Desired saving would be restricted by a elective contribution limit of $\$ 10,500$ were the employer to make no contributions to the plan. 
Table 4 continued

Total as Well as Out-of-Pocket Saving Rates by Age and Annual Earnings with No Initial Assets at Age when Saving Begins

(Married Couple with Two Children, Social Security Benefits, Increasing Earnings, and a house)

d) Saving begins at age 55

\begin{tabular}{|c|c|c|c|}
\hline & \multicolumn{3}{|c|}{ Age } \\
\hline $\begin{array}{c}\text { Earnings at } \\
\text { Age } 55\end{array}$ & $\begin{array}{l}\text { Type of } \\
\text { Savings }\end{array}$ & 55 & 60 \\
\hline \multirow{2}{*}{$\$ 25,000$} & Total & $\overline{\overline{0}}$ & 0 \\
\hline & Out-of-Pocket & 0 & 0 \\
\hline \multirow{2}{*}{$\$ 50,000$} & Total & 9.2 & 13.1 \\
\hline & Out-of-Pocket & 9.2 & 11.3 \\
\hline \multirow{2}{*}{$\$ 100,000$} & Total & 19.8 & 22.8 \\
\hline & Out-of-Pocket & 19.8 & 19.7 \\
\hline \multirow{2}{*}{$\$ 150,000$} & Total & 24.4 & 26.8 \\
\hline & Out-of-Pocket & 24.4 & 23.2 \\
\hline \multirow{2}{*}{$\$ 200,000$} & Total & 28.8 & 30.3 \\
\hline & Out-of-Pocket & $28.8^{*}$ & $26.4^{*}$ \\
\hline \multirow{2}{*}{$\$ 250,000$} & $\overline{\text { Total }}$ & 30.9 & 32.3 \\
\hline & Out-of-Pocket & $30.9 *$ & $28.2^{*}$ \\
\hline \multirow{2}{*}{$\$ 300,000$} & Total & 32.1 & 33.2 \\
\hline & Out-of-Pocket & $32.1^{*}$ & $29.0^{*}$ \\
\hline \multirow{2}{*}{$\$ 1,000,000$} & Total & 35.4 & 36.4 \\
\hline & Out-of-Pocket & $35.4^{*}$ & $32.0^{*}$ \\
\hline
\end{tabular}

The total saving rate is defined as total saving divided by total income. The out-of-pocket saving rate is defined as a) total saving minus capital income divided by $b$ ) total labor earnings.

* Desired saving would be restricted by a maximum DC contribution rate of $25 \%$ or combined total contribution of $\$ 60,000$.

Ilalics Desired saving would be restricted by a elective contribution limit of $\$ 10,500$ were the employer to make no contributions to the plan. 
Table 5(a)

- Age-35 Out-of-Pocket Saving Rates for Variants on the Base Case (Couple with Two Children, Social Security Benefits, Increasing Earnings, and Housing) with Age-35 Life-Cycle Assets

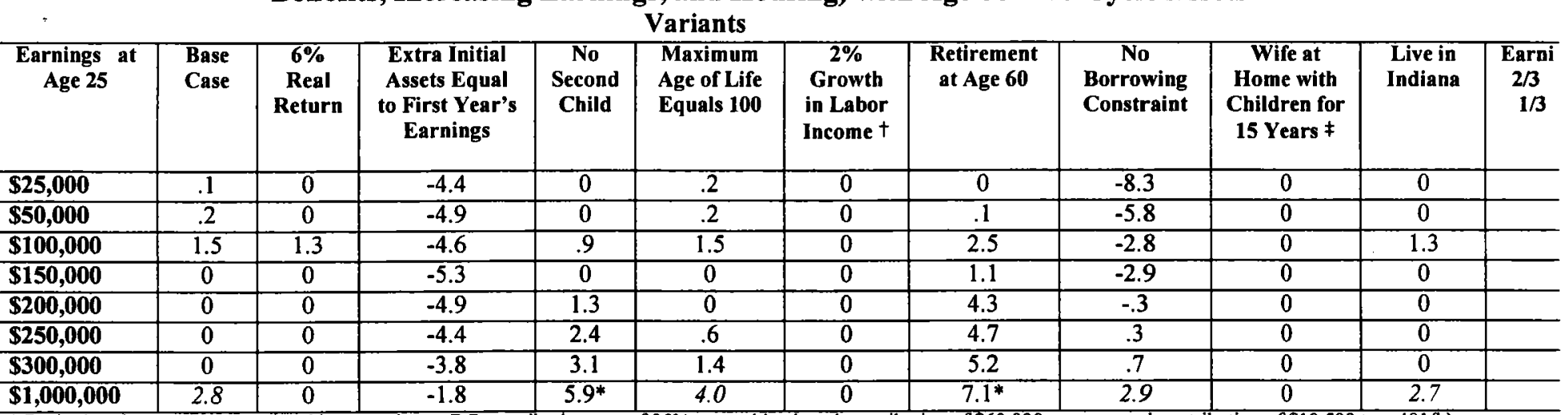

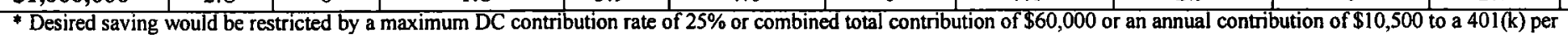
person.

† Maximum DC Contribution Rates for 2\% Growth in Labor Income scenarios are 25, 25, 25, 25, 24.6, 20, 16.4, and 5 for the respective eaming categories.

₹ Maximum DC Contribution Rates for Wife at Home scenarios are 25, 25, 25, 25, 25, 25, 20.0, and 10.8 for the respective eaming categories.

** Maximum DC Contribution Rates for Eamings Split scenarios are 25, 25, 25, 25, 21.9, 19.2, 17.4, and 5.4 for the respective eaming categories.

$\dagger \dagger$ Maximum DC Contribution Rates for Husband eaming all the income scenarios are 25, 25, 25, 18.1, 13.6, 10.9, 9.1, and 2.7 for the respective earning categories.

Italics Desired saving would be restricted by a elective contribution limit of $\$ 10,500$ were the employer to make no contributions to the plan.

Table 5(b) Age-45 Out-of-Pocket Saving Rates for Variants on the Base Case (Couple with Two Children, Social Security
Benefits, Increasing Earnings, and Housing) with Age-45 Life-Cycle Assets

\begin{tabular}{|c|c|c|c|c|c|c|c|c|c|c|c|}
\hline $\begin{array}{c}\text { Earnings at } \\
\text { Age } 25\end{array}$ & $\begin{array}{l}\text { Base } \\
\text { Case }\end{array}$ & $\begin{array}{c}6 \% \\
\text { Real } \\
\text { Return }\end{array}$ & $\begin{array}{c}\text { Extra Initial } \\
\text { Assets Equal } \\
\text { to First Year's } \\
\text { Earnings }\end{array}$ & $\begin{array}{c}\text { No } \\
\text { Second } \\
\text { Child }\end{array}$ & $\begin{array}{l}\text { Maximum } \\
\text { Age of Life } \\
\text { Equals } 100\end{array}$ & $\begin{array}{c}2 \% \\
\text { Growth } \\
\text { in Labor } \\
\text { Income } \dagger\end{array}$ & $\begin{array}{c}\text { Retirement } \\
\text { at Age } 60\end{array}$ & $\begin{array}{c}\text { No } \\
\text { Borrowing } \\
\text { Constraint }\end{array}$ & $\begin{array}{l}\text { Wife at } \\
\text { Home with } \\
\text { Children for } \\
15 \text { Years ₹ }\end{array}$ & $\begin{array}{l}\text { Live in } \\
\text { Indiana }\end{array}$ & $\begin{array}{c}\text { Earni } \\
2 / 3 \\
1 / 3\end{array}$ \\
\hline$\$ 25,000$ & -10.0 & -10.3 & -13.5 & -8.5 & -10.1 & -4.6 & -10.0 & -14.4 & -9.7 & -9.9 & \\
\hline$\$ 50,000$ & -9.7 & -9.9 & -13.3 & -8.6 & -9.7 & -5.6 & -9.6 & -13.3 & -9.5 & -9.4 & \\
\hline$\$ 100,000$ & -11.4 & -11.6 & -15.3 & -9.7 & -11.4 & -5.9 & -10.7 & -13.0 & -10.4 & -11.1 & - \\
\hline$\$ 150,000$ & -4.9 & -5.0 & -6.9 & -3.7 & -4.9 & -1.9 & -2.9 & -5.3 & -5.3 & -4.6 & \\
\hline$\$ 200,000$ & -3.7 & -3.8 & -5.9 & -.5 & -3.0 & -1.0 & -.8 & -2.4 & -4.1 & -3.5 & \\
\hline$\$ 250,000$ & -.3 & -1.7 & -2.9 & 2.9 & .5 & 1.0 & 2.2 & -.9 & 0 & $\overline{0}$ & \\
\hline$\$ 300,000$ & 2.1 &.$\overline{2}$ & -.8 & 5.1 & 2.8 & 3.0 & 4.1 & 2.7 & 1.7 & 2.3 & \\
\hline$\$ 1,000,000$ & $9.4^{*}$ & $7.7^{*}$ & $6.0^{*}$ & $11.9^{*}$ & $9.8^{*}$ & $10.3^{*}$ & $10.9^{*}$ & $9.4^{*}$ & $9.7^{*}$ & $9.7^{*}$ & \\
\hline
\end{tabular}

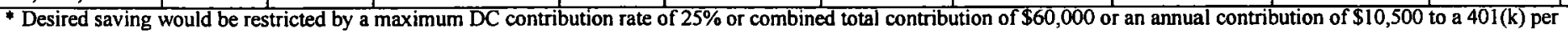
person.

† Maximum DC Contribution Rates for $2 \%$ Growth in Labor Income scenarios are 25, 25, 25, 25, 20.2, 16.2, 13.5, and 4.0 for the respective earning categories.

\$ Maximum DC Contribution Rates for Wife at Home scenarios are 25, 25, 25, 25, 25, 21.2, 17.6, and 5.2 for the respective earning categories.

** Maximum DC Contribution Rates for Eamings Split scenarios are 25, 25, 25, 24.7, 20.6, 18.2, 16.4, and 5.0 for the respective earning categories.

†† Maximum DC Contribution Rates for Husband earning all the income scenarios are 25, 25, 24.6, 16.4, 12.3, 9.8, 8.2, and 2.5 for the respective earning categories.

Italics Desired saving would be restricted by a elective contribution limit of $\$ 10,500$ were the employer to make no contributions to the plan. 
Table 5(c)

\section{Age-55 Out-of-Pocket Saving Rates for Variants on the Base Case (Couple with Two Children, Social Security Benefits, Increasing Earnings, and Housing) with Age-55 Life-Cycle Assets}

Variants

\begin{tabular}{|c|c|c|c|c|c|c|c|c|c|c|c|}
\hline $\begin{array}{c}\text { Earnings at } \\
\text { Age } 25\end{array}$ & $\begin{array}{l}\text { Base } \\
\text { Case }\end{array}$ & $\begin{array}{c}6 \% \\
\text { Real } \\
\text { Return }\end{array}$ & $\begin{array}{c}\text { Extra Initial } \\
\text { Assets Equal } \\
\text { to First Year's } \\
\text { Earnings }\end{array}$ & $\begin{array}{c}\text { No } \\
\text { Second } \\
\text { Child }\end{array}$ & $\begin{array}{l}\text { Maximum } \\
\text { Age of Life } \\
\text { Equals } 100\end{array}$ & $\begin{array}{c}2 \% \\
\text { Growth } \\
\text { in Labor } \\
\text { Income }+\end{array}$ & $\begin{array}{l}\text { Retirement } \\
\text { at Age } 60\end{array}$ & $\begin{array}{c}\text { No } \\
\text { Borrowing } \\
\text { Constraint }\end{array}$ & $\begin{array}{c}\text { Wife at } \\
\text { Home with } \\
\text { Children for } \\
15 \text { Years } ₹\end{array}$ & $\begin{array}{l}\text { Live in } \\
\text { Indiana }\end{array}$ & $\begin{array}{c}\text { Earni } \\
2 / 3 \\
1 / 3\end{array}$ \\
\hline$\$ 25,000$ & 15.0 & 13.0 & 15.3 & 13.7 & 16.0 & 16.8 & $30.5^{*}$ & $31.6^{*}$ & 15.3 & $15.0^{\circ}$ & \\
\hline$\$ 50,000$ & 19.4 & 17.3 & 19.6 & 17.1 & 20.5 & $19 . \overline{4}$ & $31.5^{*}$ & $32.6^{*}$ & 20.6 & 19.9 & \\
\hline$\$ 100,000$ & 20.9 & 19.3 & 21.1 & 17.6 & 22.0 & 22.9 & $29.4^{*}$ & $29.1^{*}$ & 21.8 & 22.0 & \\
\hline$\$ 150,000$ & 23.2 & 21.8 & 23.3 & 19.7 & $24 . I$ & $24.4^{*}$ & $27.7^{*}$ & $28.8^{*}$ & 24.2 & 23.9 & 2 \\
\hline$\$ 200,000$ & $24.6^{*}$ & $22.5^{*}$ & $23.2^{*}$ & 19.6 & $25.1^{*}$ & $25.1^{*}$ & $25.1^{*}$ & $25.8^{*}$ & $24.9^{*}$ & $25.2^{*}$ & 2 \\
\hline$\$ 250,000$ & $24.1^{*}$ & $22.6^{*}$ & $22.2^{*}$ & $19.2^{*}$ & $24.4^{*}$ & $25.0^{*}$ & $23.7^{*}$ & $24.7^{*}$ & $24.8^{*}$ & $24.7^{*}$ & 2 \\
\hline$\$ 300,000$ & $23.7^{*}$ & $22.1^{*}$ & $21.6^{*}$ & $19.3^{*}$ & $23.9^{*}$ & $24.9^{*}$ & $23.1^{*}$ & $24.2^{*}$ & $24.4^{*}$ & $24.3^{*}$ & 2 \\
\hline$\$ 1,000,000$ & $21.7^{*}$ & $19.7^{*}$ & $19.1^{*}$ & $18.0^{*}$ & $21.4^{*}$ & $24.2^{*}$ & $20.4^{*}$ & $21.7^{*}$ & $23.2^{*}$ & $22.4^{*}$ & 2 \\
\hline
\end{tabular}

" Desired saving would be restricted by a maximum DC contribution rate of $25 \%$ or combined total contribution of $\$ 60,000$ or an annual contribution of $\$ 10,500$ to a 401 (k) per person.

t Maximum DC Contribution Rates for $2 \%$ Growth in Labor Income scenarios are $25,25,25,22,16.6,13.2,11.0$, and 3.4 for the respective earning categories.

₹ Maximum DC Contribution Rates for Wife at Home scenarios are 25, 25, 25, 25, 23.9, 19.2, 15.9, and 4.8 for the respective earning categories.

** Maximum DC Contribution Rates for Earnings Split scenarios are 25, 25, 25, 23.2, 19.5, 17.2, 14.8, and 4.4 for the respective earning categories.

+ Maximum DC Contribution Rates for Husband eaming all the income scenarios are $25,25,22.3,14.8,11.1,8.9,7.2$, and 2.2 for the respective eaming categories.

Italics Desired saving would be restricted by a elective contribution limit of $\$ 10,500$ were the employer to make no contributions to the plan. 
Table 6

Life-Cycle Consumption Profiles for the Base-Case Household with \$50,000 in Annual Earnings at Age 25 for Different Rates of Contribution to a DC Plan, Assuming 4 Percent Non Tax-Favored and Tax-Favored Real Rates of Return

\section{(2000 dollars)}

\begin{tabular}{|c|c|c|c|c|c|c|c|c|c|c|}
\hline \multicolumn{11}{|c|}{ Variants } \\
\hline$\overline{\text { Age }}$ & $\begin{array}{l}\text { Base Case } \\
\text { No } \\
\text { Contribution }\end{array}$ & $\begin{array}{l}\text { Base Case } \\
\text { with No } \\
\text { Contribution } \\
\text { and No } \\
\text { Borrowing } \\
\text { Constraint }\end{array}$ & $\begin{array}{l}5 \% \\
\text { Contribution } \\
\text { Rate }\end{array}$ & $\begin{array}{l}5 \% \\
\text { Contribution } \\
\text { with No } \\
\text { Borrowing } \\
\text { Constraint }\end{array}$ & $\begin{array}{l}10 \% \\
\text { Employee } \\
\text { Contribution } \\
\text { Rate }\end{array}$ & $\begin{array}{l}10 \% \\
\text { Contribution } \\
\text { with No } \\
\text { Borrowing } \\
\text { Constraint }\end{array}$ & $\begin{array}{l}15 \% \\
\text { Employee } \\
\text { Contribution } \\
\text { Rate }\end{array}$ & $\begin{array}{l}15 \% \\
\text { Contribution } \\
\text { with No } \\
\text { Borrowing } \\
\text { Constraint }\end{array}$ & $\begin{array}{l}20 \% \\
\text { Employee } \\
\text { Contribution } \\
\text { Rate }\end{array}$ & $\begin{array}{l}20 \% \\
\text { Contr } \\
\text { with } \\
\text { Borro } \\
\text { Const }\end{array}$ \\
\hline 25 & 26,511 & $\begin{array}{c}\text { Constraint } \\
32,020\end{array}$ & 24,514 & 33,130 & 22,518 & 33,906 & 20,529 & 34,624 & 18,538 & 34 , \\
\hline 35 & 33,566 & 37,437 & 31,289 & 38,735 & 28,958 & 39,642 & 26,631 & 40,482 & 24,317 & 40 , \\
\hline 45 & 28,709 & 32,020 & 26,761 & 33,130 & 24,767 & 33,906 & 22,777 & 34,624 & 20,798 & 34, \\
\hline 55 & 32,619 & 26,124 & 39,364 & 27,030 & 42,540 & 27,663 & 40,013 & 28,249 & 37,352 & 28 , \\
\hline 65 & 32,619 & 26,124 & 39,364 & 27,030 & 47,434 & 27,663 & 58,192 & 28,249 & 68,140 & 28 \\
\hline 75 & 32,619 & 26,124 & 39,364 & 27,030 & 47,434 & 27,663 & 58,192 & 28,249 & 68,140 & 28 \\
\hline 85 & 32,619 & 26,124 & 39,364 & 27,030 & 47,434 & 27,663 & 58,192 & 28,249 & 68,140 & 28 \\
\hline 95 & 32,619 & 26,124 & 39,364 & 27,030 & 47,434 & 27,663 & 58,192 & 28,249 & 68,140 & 28 \\
\hline
\end{tabular}

Table 7

Life-Cycle Consumption Profiles for the Base-Case Household with \$50,000 in Annual Earnings at Age 25 for Different Rates of Contribution to a DC Plan, Assuming 7 Percent Non Tax-Favored and Tax-Favored Real Rates of Return

\section{(2000 dollars)}

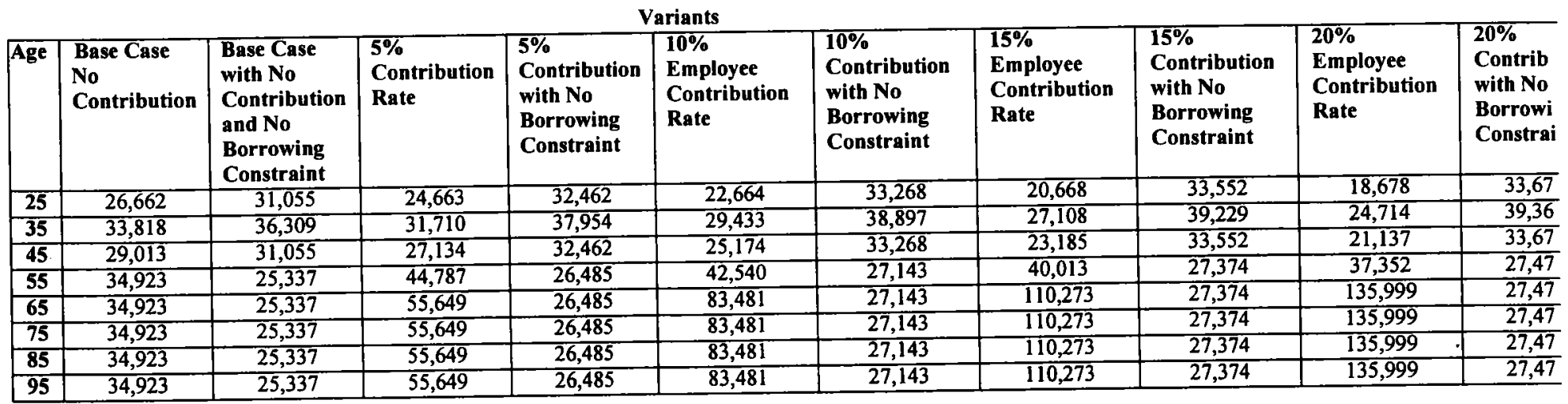


Table 8

Tax Benefit for Base-Case Household from Participating in a DC Plan

(Measured as Percent of Lifetime Consumption at 16.5 percent contribution rate* for Alternative Rates of Return and Levels of Annual Earnings at Age 25)

Real Rate of Return on Tax-Favored and Non Tax-Favored Assets

\begin{tabular}{|l|c|c|c|c|c|}
\hline Earnings at Age 25 & $\mathbf{2 \%}$ & $\mathbf{4 \%}$ & $\mathbf{6 \%}$ & $\mathbf{8 \%}$ & $\mathbf{1 0 \%}$ \\
\hline $\mathbf{\$ 2 5 , 0 0 0}$ & 3.96 & 1.89 & .59 & -1.53 & -3.26 \\
\hline $\mathbf{\$ 5 0 , 0 0 0}$ & 3.21 & 1.97 & .11 & -1.94 & -3.88 \\
\hline $\mathbf{\$ 1 0 0 , 0 0 0}$ & 4.25 & 3.45 & 1.88 & -.07 & -1.47 \\
\hline $\mathbf{\$ 1 5 0 , 0 0 0}$ & 4.77 & 4.52 & 2.26 & .29 & -1.05 \\
\hline $\mathbf{\$ 2 0 0 , 0 0 0}$ & 7.66 & 6.63 & 4.11 & 2.02 & .54 \\
\hline $\mathbf{\$ 2 5 0 , 0 0 0}$ & 10.35 & $\mathbf{8 . 8 3}$ & 5.71 & 3.66 & 2.19 \\
\hline $\mathbf{\$ 3 0 0 , 0 0 0}$ & 11.05 & 9.80 & 6.46 & 4.22 & 2.78 \\
\hline $\mathbf{\$ 1 , 0 0 0 , 0 0 0}$ & 7.19 & 7.67 & 7.21 & $\mathbf{6 . 4 8}$ & 4.31 \\
\hline
\end{tabular}

Subsidy is calculated as the percentage difference in the present value of the household's lifetime consumption, discounted at a the specified real rate of return (the assumed return on both tax-favored and non tax-favored assets) to age 25 .

${ }^{*}$ For $\$ 1,000,000$ earnings, the $10 \%$ contribution rate was constrained to the limit of a $\$ 60,000$ annual contribution. 


\section{Appendix}

\section{ESPlanner's Tax and Social Security Benefit Calculations}

\section{Federal Income Tax Calculations}

ESPlanner's calculations of federal income taxes in each future year take into account the household's yearspecific marital status. Thus, in the case of married households, the marital status is married when both spouses are alive and single when on is deceased. Households that are married are assumed to file jointly. The tax schedules for each filing status are taken from the federal income tax booklet for the latest available tax yearusually the year prior to the "current" year entered by the user. The tax schedule is applied to the program's calculation of federal taxable income. Federal taxable income equals federal Adjusted Gross Income (AGI) less personal exemptions and less the standard or itemized deduction, whichever is larger.

AGI for each year includes projected incomes in current dollars from the following sources: Labor income (wages and salaries), self-employment income, asset income projected by the program based on user inputs of initial non-tax-favored net worth and rates of return, and on the optimal spending plan computed by the program. AGI also includes taxable asset income, taxable social security benefits, taxable special receipts, taxable distributions from defined benefit pension plans and taxable withdrawals from tax-favored saving plans. Each of these items is based upon the user's inputs and preferences. Non-taxable special receipts and withdrawals from non-deductible tax-favored accounts are not included in AGI. Deductible contributions to tax-favored retirement accounts are subtracted from income in calculating each year's AGI. Employer contributions to tax-favored retirement accounts are not included in AGI. However, withdrawals from these accounts are included.

\section{The Tax Schedule}

The tax schedules for the two types of filing statuses implemented in ESPlanner are taken from the federal income tax booklet for the 1998 tax year-the latest year for which the federal schedules are available. These schedules are as follows:

(1)

\section{If taxable}

\section{income}

is over--
(2)

but not

over--
(3)

the tax

is--
(4)

of the

amount

over--

Married filing jointly:

$\$ 0$

42,350

102,300

155,950

278,450

Single:

$\$ 0$

25,350

61,400

128,100

278,450
$\$ 42,350$

102,300

155,950

278,450

--------

$15 \%$
$-\$ 6,352.50+28 \%$
$23,138.50+31 \%$
$39,770.00+36 \%$
$83,870.00+39.6 \%$

-------- $15 \%$

$\$ 3,802.50+28 \%$

$13,896.50+31 \%$

$34,573.50+36 \%$

$88,699.50+39.6 \%$
$\$ 0$

42,350

102,300

155,950

278,450

$\$ 0$

25,350

61,400

128,100

278,450

\section{The Indexation of the Tax Schedule}

Tax-rate brackets and infra-marginal tax amounts (all of the dollar amounts listed in the tax schedules) are adjusted for inflation in each year over the household's lifetime. This is done to ensure that the schedule keeps 
pace with the growth of income in current dollars. The indexation is done using the user-specified rate of inflation.

\section{Adjustment for the current year}

Because the tax schedules listed above are applicable for the 1998 tax year whereas the user will enter 1999 as the current year, all tax brackets and infra-marginal tax amounts [the dollar amounts shown in column (3) in the schedules listed above] are indexed for inflation at the user-specified annual rate. This is done to avoid subjecting 1999 taxable income to tax schedules appropriate for 1998-that is, based on the wage and price levels prevailing in 1998.

\section{Standard Deductions and Exemptions}

The standard deduction and personal exemption amounts are also taken from the tax year prior to the "current" year (tax year 1998 in the current version). The amount subtracted from AGI for each personal exemption was $\$ 2,700$. The standard deductions were $\$ 7,100$ for the "married filing jointly" filing status and $\$ 4,250$ for the "single" filing status. These amounts are also indexed for inflation for each future year based on the userspecified future rate of inflation. The number of personal exemptions allowed equals 2 plus the number of children for "married and filing jointly" and 1 plus the number of children for the "single" filing statuses. The personal exemption amount that can be deducted from AGI in calculating taxable income is phased out if AGI is above certain dollar limits depending upon the filing status. ESPlanner takes account of the phase-out of personal exemptions based on these dollar limits indexed for inflation.

\section{The Decision to Itemize}

ESPlanner takes the maximum of the standard deduction or itemized deduction where the latter includes mortgage interest payments, property taxes, state and local income tax payments, and tax-deductible special expenditures that the user specifies - such as alimony payments, charitable contributions, and deductible medical expenses. Note that state and local income tax payments are deductible only if they are being withheld from pay or the user makes estimated tax payments during the during the tax year. ESPlanner assumes withholding or pre-payment in every case.

\section{The Phase Out of Itemized Deductions}

Federal income tax rules phase out itemized deductions for high income taxpayers (both, married filing jointly and single payers). For the 1998 tax year, the amount of the deduction is reduced by $3 \notin$ for every dollar of AGI in excess of $\$ 124,500$ with the total reduction limited to 80 percent of the original amount. The reduction does not apply to certain components of the itemized deductions claimed-such as medical care expenses, investment interest, and casualty and theft losses. Because ESPlanner does not distinguish between these. and other sources of itemized deductions, the phase-out rules are applied to the entire itemized deduction.

\section{The Child Tax Credit}

The child tax credit equals $\$ 400$ times the number of qualifying children in the household. The tax credit is phased out if AGI is over the threshold of $\$ 110,000$ for the "married and filing jointly" status and of $\$ 75,000$ for the "single" filing status. The phase-out rate is $\$ 50$ for each $\$ 1000$ of income in excess of the applicable threshold. The amount of the child tax credit equals the computed amount or the federal income tax liability net of the earned income tax credit, whichever is less. If the earned income tax credit exceeds the federal income tax liability, the child tax credit is applied against the payroll tax liability.

\section{The Earned Income Credit}

The program's calculation of the earned income credit adheres to the EIC worksheet in federal Form 1040. ESPlanner first checks for eligibility to take EIC based on investment income and on taxable and non-taxable (employer contributions to $401 \mathrm{k}$ plans, for example) earned income thresholds for households with no qualifying child and those with at least one qualifying child (adopted, foster, step-and grand-children are 
excluded in ESPlanner's calculations). Next, EIC is computed based on the EIC schedule for taxable and nontaxable income. If the EIC is non-zero, it applies if AGI is less than certain dollar thresholds ( $\$ 5600$ for - households without a qualifying child and $\$ 12,300$ for households with at least 1 qualifying child). If $A G I$ is greater than these dollar amounts, EIC is based on the AGI.

\section{Payroll Taxes}

In each year, the payroll tax for a married household is the sum of the two spouses' payroll taxes. Each spouse's tax equals the employee share of the OASDI tax rate (6.2 percent) applied to labor earnings up to the taxable maximum level plus the employee share of the HI tax rate ( 1.45 percent) applied to total labor earnings. If earnings from self-employment are present, these are included in the calculation only to the extent that labor earnings fall short of the taxable maximum limit for the OASDI tax. The entire labor income from selfemployment in taxed on account of the HI tax. In the case of self-employment income, the employer plus employee tax rates for OASDI and HI are applied.

\section{The Taxation of Social Security Benefits}

Social Security benefits are taxed by including these benefits in the federal income tax base in the following manner. If the sum of AGI and 50 percent of Social Security benefits falls short of $\$ 25,000$ (adjusted for inflation for future years) if single and $\$ 32,000$ (same qualifier) if married, then none of the benefits are taxable. If the sum exceeds the applicable dollar threshold, but the excess is less than $\$ 9,000$ if single ( $\$ 12,000$ if married), then the smaller of one-half of the excess or 50 percent of the benefit is taxable and is included in the federal income tax base. In addition, if the aforementioned excess is greater than the dollar thresholds, 85 percent of this excess or 85 percent of the benefit, whichever is smaller, is also added to the federal income tax base.

\section{State Income Tax Calculations}

State income taxes are calculated for each state that imposes an income tax according to the specific tax rules applicable in user's state of residence. In most cases, the state income tax base equals the federal AGI readjusted for taxable Social Security benefits. State income tax calculations incorporate special features peculiar to each state: For example, some states (such as Massachusetts) impose special taxes on asset incomes. Statespecific personal, spousal, and dependent exemptions (including additional exemptions for the elderly) and the applicable standard deductions are used to calculate the state taxable income. State taxes are calculated by applying the state's tax rate schedule to the taxable income.

\section{Social Security Benefit Calculations \\ Retirement Benefits}

Eligibility - Before ESPlanner provides you (and your spouse if married) Social Security retirement benefits, it checks that you are fully insured. Individuals must be fully insured to receive retirement benefits based on their earnings records. Becoming fully insured requires sufficient contributions at a job (including self-employment) covered by Social Security. For those born after 1929, acquiring 40 credits prior to retirement suffices for fullyinsured status. Earnings between 1937 and 1951 are aggregated and divided by $\$ 400$, and the result (rounded down to an integer number) are the pre-1952 credits which are added to the credits earned after 1950 in determining insured status. After 1951, workers earn one credit for each quarter of the year they work in Social Security-covered employment and earn above a specified minimum amount. The year of first eligibility for retirement benefits is the year in which the individual becomes age 62 . The individual is entitled to retirement benefits after an application for benefits is submitted, but never before age 62 .

Determination of Primary Insurance Amount (PIA) -- The PIA is the basis for all benefit payments made on a worker's earnings record. There are several steps in computing the PIA. Base years are computed as the years after 1950 up to the first month of entitlement to retirement benefits begins. For survivor benefits, base years include the year of the worker's death. 
Elapsed years are computed as those years after 1950 (or after attainment of age 21, whichever occurs later) up to (but not including) the year of first eligibility. The maximum number of elapsed years for an earnings record is 40 (it could be shorter, for purposes of calculating survivor benefits if the person dies prior to age 62).

Computation years are calculated as the number of elapsed years less 5, or 2, whichever is greater. Earnings in base years (up to the maximum taxable limit in each year, and through age 60 or two years prior to death, whichever occurs earlier) are wage-indexed according to economy-wide average wages. Of these, the highest earnings in years equaling the number of computation years are added together and the sum is divided by the number of months in computation years to yield Average Indexed Monthly Earnings (AIME).

Bend Points -- The AIME is converted into a PIA using a formula with bend points. The bend point formula is specified as 90 percent of the first X dollars of AIME plus 32 percent of the next $Y$ dollars of AIME plus 15 percent of the AIME in excess of $Y$ dollars. The dollar amounts $X$ and $Y$ are also wage indexed and are different for different eligibility years. The dollar amounts pertaining to the year of attaining age 60 (or, for survivor benefits, the second year before death, whichever is earlier) are applied in computing the PIA.

Benefits- A person who begins to collect benefits at his or her "normal retirement age" (currently age 65) receives the PIA as the monthly retirement benefit. In subsequent years, the monthly benefit is adjusted according to the Consumer Price Index (CPI) to maintain its purchasing power.

Increases in Normal Retirement Ages -- After 2003 normal retirement ages are scheduled to increase by 2 months for every year that a person's 65 th birthday occurs later than the year 2003. This progressive increase in the normal retirement age for those born later ceases between the years 2008 through 2020; those attaining age 65 in these years have a normal retirement age of 66 . The postponement in retirement ages resumes after 2020 such that those born after 2025 have a normal retirement age of 67 . All cohorts attaining age 65 after that year have a normal retirement age of 67 .

Reductions for Age -- A person who begins to collect retirement benefits earlier than the normal retirement age receives a reduction for age. The reduction factor is $5 / 9$ of 1 percent for each month of entitlement prior to the normal retirement age. The reduced benefit payment (except for the inflation adjustment) continues even after the person reaches or surpasses the normal retirement age. If the number of months of reduction exceeds 36 months (for example, in case of entitlement at age 62 when the normal retirement age is 67 ), then the reduction factor is $5 / 12$ of 1 percent for every additional month of early entitlement.

Delayed Retirement Credits--Those who begin to collect benefits after their normal retirement age (up to age 70) receive delayed retirement credits. The amount of the delayed retirement credit for each month of delayed entitlement depends on the year in which a person attains normal retirement age. For example, those attaining age 65 in 1997 receive an additional 5 percent in monthly benefits for each year of delay in entitlement. However, those attaining age 65 in the year 2008 will receive an additional 8 percent in benefits for each year of delayed entitlement.

Earnings Test -- If a person continues to work and earn after the month of entitlement, benefits are reduced because of an earnings test. Beneficiaries under the normal retirement age, lose $\$ 1$ for each $\$ 2$ earned above an earnings limit. Those older than the normal retirement age, lose $\$ 1$ for each $\$ 3$ earned above a higher earnings limit. The earnings limits have already been specified through the year 2000 and are scheduled to grow with average wages in subsequent years. All benefits payable on a worker's earnings record, including the worker's own retirement benefits and spousal and child dependent benefits, are proportionally reduced by the testing of the worker's earnings. 
- Recomputation of Benefits -- Earnings in any year after entitlement to benefits are automatically taken into account in a recomputation of the PIA for determining the subsequent year's benefit amount. However, these

- earnings are not indexed before they are included in the AIME calculation. If such earnings are higher than some prior year's earnings (indexed earnings through age 60 or unindexed earnings after age 60), they result in an increase in the PIA and benefit payable. If they are lower than all previous year's earnings, they will not lower the PIA or benefits since only the highest earnings in base years are included in the calculations.

\section{Spousal and Child Dependent Benefits}

Eligibility -- Wives and husbands of insured workers (including divorced spouses) are entitled to spousal benefits if the couple was married for at least 10 years at the time of application for spousal benefits, the spouse is over age 62 or has in care a child under age 16 entitled to benefits under the insured worker's record, and the insured worker is collecting retirement benefits. Children of insured workers under age 16 are entitled to child dependent benefits if the child is unmarried and the worker is collecting retirement benefits.

Benefits -- Spousal and child benefits equal 50 percent of the insured worker's PIA (each). Child dependent benefits may be lower only if the family maximum applies. Spousal benefits may be lower due to the family maximum, a reduction for age, the application of the earnings test, or the spouse's receipt of retirement benefits based or her or his own earnings record.

Family Maximum -- All benefits paid under a worker's record (except retirement benefits or divorced spousal benefits) are reduced proportionately to bring them within the family maximum benefit level. The maximum benefits payable on a worker's earnings record is determined by applying a bend point formula to the PIA similar to that applied to the AIME in calculating the PIA. For example, the family maximum equals 150 percent of the first $\$ X$ of PIA plus 272 percent of the next $\$ Y$ of the PIA plus 134 percent of the next $\$ Z$ of the PIA plus 175 percent of the PIA greater than $\$ X+\$ Y+\$ Z$. The values $X, Y$, and $Z$ are adjusted for each year of the calculation according to the growth in economy-wide average wages. In case the spousal benefit is eliminated for any reason, the benefits payable on the insured worker's record are subjected to the family maximum test again, treating the spouse as though he/she were not eligible for spousal benefits. This may result in higher benefits for children who may be eligible for dependent benefits under the worker's record.

Reduction of Spousal Benefits for Age -- Spouses eligible for the spousal benefit may elect to receive (may become entitled for) their benefits before normal retirement age. In this case the spousal benefit is reduced by $25 / 36$ of 1 percent for each month of entitlement prior to normal retirement age. If the number of months of reduction exceeds 36 months (for example, in case of entitlement at age 62 when the normal retirement age is 67 ), then the reduction factor is $5 / 12$ of 1 percent for every additional month of early entitlement.

Earnings Testing and Redefinition of Spousal Benefits -- If a spouse is earning above the amount allowed by the earnings test, the spousal benefits he or she is eligible to receive will be earnings tested according to the preand post-normal retirement schedule described above. If a spouse is already collecting retirement benefits, the spousal benefit is redefined as the greater of the excess of the spousal benefit over the spouse's own retirement benefit or zero.

\section{Survivor Benefits (Widow(er), Father/Mother, and Children)}

Eligibility-- The surviving spouse of a deceased worker is eligible for widow(er) benefits if the widow(er) is at least age 60, is entitled (has applied for widow[er] benefits), the worker died fully insured, and the widow(er) was married to the deceased worker for at least 9 months. The widow(er) of a deceased worker is eligible for father/mother benefits if the widow(er) is entitled to benefits (has applied), the worker died fully insured, the widower has in care a child of the worker. A surviving child is eligible for child survivor benefits on the deceased worker's record if the child is under age 18 and is entitled (an application has been filed) and the worker was fully insured. 
Survivor Benefits-- Monthly benefits equal 100 percent of the worker's PIA for a widow(er); they equal 75 - percent of the PIA for father/mother and child survivor benefits. Widow(er) and child survivor benefits may be lower only if the family maximum applies. Widow(er)s may become entitled to (elect to receive) survivor benefits earlier than normal retirement age, but not earlier than age 60 . In this case the reduction is $19 / 40$ of 1 percent for each month of entitlement prior to normal retirement age. After the widow(er) is 62 , he or she is may become entitled to (elect to receive) retirement benefits based on her own past covered earnings record. In this case the widow(er) benefits are redefined as the excess over own retirement benefit or zero, whichever is greater. Finally, widow(er) survivor and own retirement benefits are also subject to the earnings test. If the deceased worker was already collecting a reduced retirement insurance benefit, the widow(er)'s benefit cannot be greater than the reduced widow(er) benefit or the greater of 82.5 percent of the worker's PIA or the worker's own retirement benefit. If the deceased worker was already collecting a retirement insurance benefit greater than the PIA because of delayed retirement, the widow(er) or is granted the full dollar amount of the delayed retirement credit over and above the (reduced) widow(er) benefit. Father/mother benefits are not similarly augmented by delayed retirement credits that the deceased worker may have been receiving.

Father/Mother Benefits -- These benefits may be reduced if the family maximum applies or if the father or mother is entitled to the own retirement benefit. In this case the father/mother benefit is redefined as the excess over the father or mother's own retirement benefit or zero, whichever is greater. Father /mother benefits are also subject to the earnings test. On the other hand, they are not reduced for age. For those eligible to receive both widow(er) and father/mother benefits, the program calculates both and takes the larger benefit.

Calculation of a Deceased Worker's PIA -- The calculation of survivor benefits in the case of a widow(er) benefits uses the larger of two alternative calculation's of the deceased worker's PIA. These are the "wage indexing" method and the "re-indexing" method. Moreover, the year up to which the worker's wages are indexed may be different depending upon whether the deceased worker would have become age 62 before or after the widow(er) attains age 60 .

The wage-indexing method -- the last year for indexing earnings is the earlier of a) the year the worker dies minus 2 years or b) the year worker would have attained age 60 . Bend point formula dollar amounts are taken from the earlier of the year the worker dies or the year the worker would have attained age 62. The PIA thus calculated is inflated by the CPI up to the year the widow(er) turns age 60 (if later) to obtain the PIA value on which widower benefits would be based. Where applicable, these benefits are then adjusted for the family maximum, reduction for age, delayed retirement credits, and the earnings test.

The reindexing method -- The worker's original earnings are indexed up to the earlier of the year the widow(er) attains age 58 or b) the year the worker attains age 60 . The elapsed years are computed as the number of years from 1951 (or the worker's age 22 if later) through the year the widow(er) attains age 60. The computation years equal elapsed years minus 5 years (computation years cannot be less than 2). Bend point formula dollar values are applied from the year the widow(er) attains age 60. There is no subsequent indexing of the PIA for inflation.

The Sequencing of Widow(er) Benefit Calculations -- Widow(er) benefit reductions follow these steps: First the widow(er) plus children's benefits are subjected to the family maximum. Second, the widow(er) benefit is reduced for early entitlement (of the widow(er) prior to normal retirement age). Third, the widow(er) benefit is compared to the widow(er) own retirement benefit if entitled to the latter. Fourth, the widow(er) benefit is redefined as the excess over own benefit if own benefit is positive. Finally the earnings test is applied, first to the widow(er)'s own benefit and then to the widow(er) benefit that is in excess of own benefit. If the widow(er) benefit is eliminated as a result of these tests, the benefits payable on the insured worker's record are subjected to the family maximum test again, treating the widow(er) as though he/she were not eligible for the widow(er) 
- benefit. This procedure can potentially increase children's benefits if the family maximum limit was binding the first time through. 